Article

\title{
Candida Species (Volatile) Metabotyping through Advanced Comprehensive Two-Dimensional Gas Chromatography
}

\author{
Carina Pedrosa Costa ${ }^{1}\left[\right.$, Ana Rita Bezerra ${ }^{2}$, Adelaide Almeida ${ }^{3, *}$ a and Sílvia M. Rocha ${ }^{1, *(D)}$ \\ 1 Department of Chemistry \& LAQV-REQUIMTE, University of Aveiro, Campus Universitário Santiago, \\ 3810-193 Aveiro, Portugal; carina.pedrosa@ua.pt \\ 2 Health Sciences Department, Institute for Biomedicine-iBiMED, University of Aveiro, \\ Campus Universitário Santiago, 3810-193 Aveiro, Portugal; armbezerra@ua.pt \\ 3 Department of Biology \& CESAM, University of Aveiro, Campus Universitário Santiago, \\ 3810-193 Aveiro, Portugal \\ * Correspondence: aalmeida@ua.pt (A.A.); smrocha@ua.pt (S.M.R.); Tel.: +351-234-370784 (A.A.); \\ +351-234-401524 (S.M.R.)
}

Received: 5 November 2020; Accepted: 29 November 2020; Published: 30 November 2020

\begin{abstract}
Microbial metabolomics is a challenge strategy that allows a comprehensive analysis of metabolites within a microorganism and may support a new approach in microbial research, including the microbial diagnosis. Thus, the aim of this research was to in-depth explore a metabolomics strategy based on the use of an advanced multidimensional gas chromatography for the comprehensive mapping of cellular metabolites of C. albicans and non-C. albicans (C. glabrata and C. tropicalis) and therefore contributing for the development of a comprehensive platform for fungal detection management and for species distinction in early growth times $(6 \mathrm{~h})$. The volatile fraction comprises 126 putatively identified metabolites distributed over several chemical families: acids, alcohols, aldehydes, hydrocarbons, esters, ketones, monoterpenic and sesquiterpenic compounds, norisoprenoids, phenols and sulphur compounds. These metabolites may be related with different metabolic pathways, such as amino acid metabolism and biosynthesis, fatty acids metabolism, aromatic compounds degradation, mono and sesquiterpenoid synthesis and carotenoid cleavage. These results represent an enlargement of ca. $70 \%$ of metabolites not previously reported for $C$. albicans, $91 \%$ for C. glabrata and $90 \%$ for C. tropicalis. This study represents the most detailed study about Candida species exometabolome, allowing a metabolomic signature of each species, which signifies an improvement towards the construction of a Candida metabolomics platform whose application in clinical diagnostics can be crucial to guide therapeutic interventions.
\end{abstract}

Keywords: Candida species; microbial metabolomics; solid phase microextraction; comprehensive two-dimensional gas chromatography; Candida spp. distinction; metabotyping

\section{Introduction}

Fungal pathogens can cause life threatening invasive infections (fungemia and meningitis), chronic conditions (asthma) and recurrent superficial infections (oral and vaginal candidiasis). Globally, the death toll has been estimated to be around 1.6 million deaths per year [1]. Species belonging to the genera Aspergillus, Candida and Cryptococcus are the most prevalent cause of invasive infections, and recent data indicate that Candida infections account for $80 \%$ of all systemic fungal infections worldwide [2]. The epidemiology of Candida infections is constantly changing due to changes in medical practices, but approximately $95 \%$ of all cases of Candida infections result from five species: Candida albicans, Candida glabrata, Candida parapsilosis, Candida tropicalis and Candida krusei [2]. 
Candida spp. exist as commensals of the skin, mouth and gastrointestinal tract. Their growth and spread are controlled by epithelial barriers and defenses of the innate immune system. While Candida spp. are normal flora of the human body, they also possess the ability to transition to pathogens causing life-threatening systemic infections [3-5]. Additionally, the presence of candidemia results in an increase in mortality and costs associated with prolonged hospitalization, making Candida spp. not only a clinical concern but also an economic concern as well [6].

C. albicans is present on the human microflora as a diploid yeast. One of the hallmark features of C. albicans is its phenotypic plasticity that promotes adaptation inside the host. This plasticity includes growing with distinct morphologies, yeast, hyphae, pseudohyphae and chlamydospores. Yeast cells have a round/oval shape, similar to Saccharomyces cerevisiae morphology that contrasts with the thin and tube-shaped morphology of hyphal cells [7]. Both morphological forms seem to have distinct functions during the different stages of infection, including adhesion, invasion, damage, dissemination, immune evasion and host response. The hyphal form has been shown to be more invasive while the smaller yeast form is believed to be mainly involved in dissemination $[7,8]$. The other main characteristic that establishes $C$. albicans as a successful pathogen is its huge adaptability, allowing it to grow on the most diverse microenvironments in the host niches (with different nutrient availability, $\mathrm{pH}$, hypoxia and $\mathrm{CO}_{2}$ levels) $[9,10]$. Unlike many other commensal microbes, that require specific carbon sources in order to proliferate (e.g., glucose), C. albicans has the capacity of metabolizing a diversity of carbon sources present in different host niches, such as sugars, fatty acids, amino acids and short chain carboxylic acids (lactate) by differential activation of glycolysis, gluconeogenesis or the glyoxylate cycle. Besides that, C. albicans is also able to mount strong stress responses and can survive periods of starvation, providing it the fitness attributes that are crucial for its survival in the hostile environment of the host $[10,11]$.

In the phylogenetic tree, C. glabrata and C. albicans are separated by several non-pathogenic yeasts, suggesting that the ability to infect humans has evolved independently [12]. Differences between the two species include the fact that C. glabrata is strictly haploid and only grows in the yeast form. Additionally, unlike the high metabolic flexibility of C. albicans, C. glabrata appears more specialized in its metabolic requirements [13]. In fact, C. glabrata lacks many of the metabolic pathways known in other yeasts. For example, it cannot catabolize galactose and allantoin, and is auxotrophic for pyridoxine, nicotinic acid and thiamine [12]. C. tropicalis exhibits several phenotypic traits associated with C. albicans, namely the ability to produce true hyphae and biofilms [14].

In clinical laboratories, fungal infections can be detected based on conventional methods, such as cell culture and following identification by phenotypic, immunologic and genotypic methods [15]. While culture and microscopy remain the standard techniques for diagnosis, sensitivity and specificity of such methods are limited [16-18]. Immunologic tests are not suitable for immunocompromised patients, for which fungal infection is a serious problem, although they allow faster results. Therefore, several commercial PCR-based detection methods are now available for a more sensitive and targeted diagnostic of fungal infections [15,19]. Additionally, other molecular methods are being developed for rapid detection of antifungal resistance [20]. The delayed diagnosis and therapy contribute to the high mortality rates, thus the development and implementation of rapid, accurate and cost-effective laboratory diagnosis is very important to provide help and selection of appropriate antifungal therapy, alongside the enhanced drug stewardship [19,21,22].

Microbial metabolomics is a comprehensive analysis of metabolites within a microorganism that may help to better understand complex biological systems and supports a new approach in microbial research, including the microbial diagnosis. The microorganisms produce a wide range of metabolic products, which are the final products of biochemical processes and a result of environmental and genetic interactions, such as volatile metabolites that can be used as unique volatile metabolic fingerprints of each species, and possibly of strains [21,23,24]. Genetic differences promote differential expressions of genes implicated in the biosynthesis of volatile metabolites, or even promote different metabolites concentrations $[23,24]$. Metabolomic profiling may provide additional information about the processes 
affected by specific microorganisms or microbiota alterations or about the environment affects the organisms that are susceptible to environmental changes and stress conditions [24,25].

Some studies are already performed regarding the profiling of volatiles metabolites from C. albicans and non-C. albicans, such as, C. glabrata and C. tropicalis. A visual representation was constructed using the data available in the literature for the $C$. albicans, $C$. glabrata and C. tropicalis (Figure 1): the nodes represent Candida species and the lines make the connection between species and metabolites, some of them common to 2 or 3 species [26-35]. This figure unveils that limited information is currently available about the metabolomics profile of these Candida species. The benzaldehyde, dimethylethyl cyclohexanol, ethanol, 2-methyl-1-propanol, 2-methyl-1-butanol, 3-methyl-1-butanol, 2-phenylethanol, 2-ethyl-1-hexanol, 2-propanone, 6-methyl-5-hepten-2-one, ethyl acetate, ethyl butanoate and E,E-farnesol are the most cited metabolites (Figure 1). The common metabolites among the three Candida species are ethanol, 1-propanol, 1-pentanol, 2-methyl-1-propanol, 2-methyl-1-butanol, 3-methyl-1-butanol, 2-phenylethanol, ethyl acetate, ethyl propanoate, propyl acetate, isobutyl acetate, ethyl butanoate, 2-pentanone, 3-octanone and dimethyl disulfide. Particular attention has been given to E,E-farnesol, an extracellular quorum sensing molecule produced by C. albicans [36], that represses the induction of hyphal growth by yeast cells in many different environments [37]. This metabolite was already reported for C. tropicalis [34].

In fact, these microbial metabolomics studies used in general one-dimensional gas chromatography (1D-GC) $[26,28,30-35]$, however, the data from their metabolome may be enlarged if a high sensitive and high throughput technique will be used. Recent advances in metabolomics studies applied to a wide range of microbes have been used successfully using the comprehensive two-dimensional gas chromatography coupled to mass spectrometry with a time of flight analyzer (GC $\times$ GC-ToFMS) $[21,23,27,38-43]$. GC $\times$ GC employs two orthogonal mechanisms to separate the constituents of the sample within a single analysis, based on the application of two GC columns coated with different stationary phases. The interface samples small (several seconds) portions of the first dimension $\left({ }^{1} \mathrm{D}\right)$ eluate, in general, by cryofocusing, and reinjects them into the second column $\left({ }^{2} \mathrm{D}\right)$. Each ${ }^{1} \mathrm{D}$ peak is modulated several times, largely preserving the ${ }^{1} \mathrm{D}$ separation. Using this instrumental approach, compounds coeluting from ${ }^{1} \mathrm{D}$ undergo additional separation on ${ }^{2} \mathrm{D}$ [4]. Therefore, sensitivity and limits of detection (LoD) are improved due to focusing of the peak in the modulator and separation of analytes from the chemical background $[44,45]$. The signal-to-noise ratio was enhanced for GC $\times$ GC, compared to D-GC. Additionally, the combination of the GC $\times$ GC and a mass spectrometer, with a time-of-flight analyzer (ToFMS), allowed the detection and quantification of analytes in the range of pg. Indeed, the narrow peaks produced by GC $\times$ GC (peak width at half height of $0.1 \mathrm{~s}$ or less) require a detector with high data acquisition speed (ca. hundred full-mass-range spectra per second), such as ToFMS, thus providing sufficient data density. Moreover, ToFMS allows the acquisition of full mass spectra at trace levels and mass spectral continuity, letting a reliable spectra deconvolution of overlapping peaks.

Thus, the aim of this research was to in-depth explore a metabolomics strategy for the comprehensive mapping of cellular metabolites of pathogens, namely C. albicans, C. glabrata and C. tropicalis, therefore contributing for the development of a comprehensive platform for fungal detection management and for species distinction in early growth times $(6 \mathrm{~h})$. Due to its high clinical relevance, in this study particular attention was done for $C$. albicans, and for comparative purposes, other non-C. albicans species were also studied. The metabolomic profiles were characterized during a time-course experiment through a methodology based on headspace solid-phase microextraction (HS-SPME), a green and solvent free extraction technique, combined with GC $\times$ GC-ToFMS. The metabolomics data were subjected to hierarchical cluster analysis, allowing differentiation between the Candida spp. This study also allowed the identification of a large set of new compounds compared to previous studies, representing an improvement towards the construction of a Candida spp. omics pipeline. Finally, the set of identified metabolites was integrated, as possible, in the corresponding pathways network associated with yeasts metabolism. Although further studies are needed, our work intends to improve knowledge on the metabolic flexibility of Candida species as a strategy for virulence. 


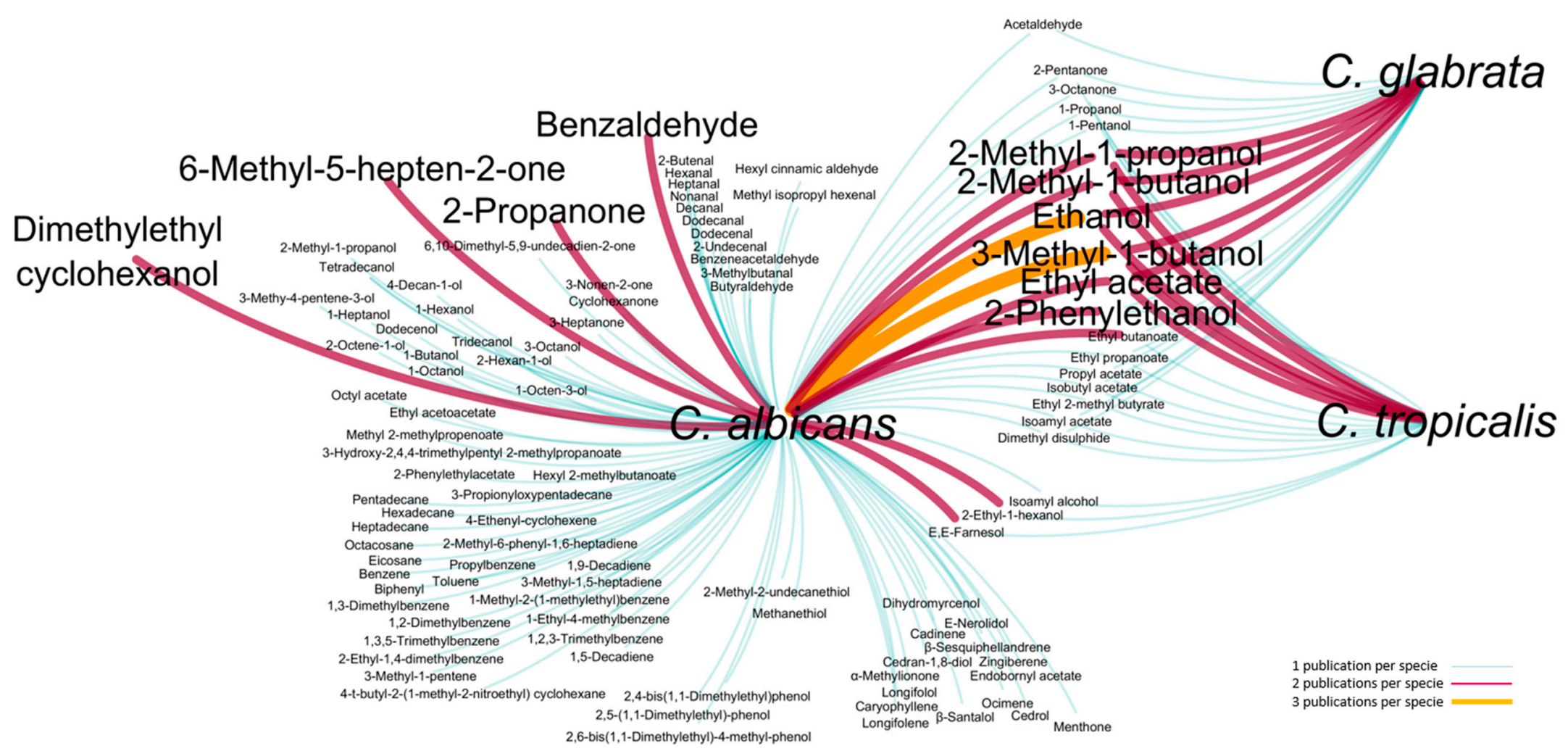

Figure 1. Visual representation of the volatile metabolites reported in the literature for the C. albicans, C. glabrata and C. tropicalis. Nodes represent Candida species, and the lines make the connection between species and metabolites, some of them common to 2 or 3 species. The color and line thickness represent the number of citations of each metabolite per specie: 1 (white blue), 2 (violet) and 3 (orange) publications [26-35]. 


\section{Materials and Methods}

The fungi growth, sample preparation and extraction, instrumental analysis and information relative to data preprocessing, pretreatment, processing and interpretation were done according to the metabolomics standards initiative (MSI) [46-48]. The main stages of experimental procedure were performed according to Figure 2, and include yeast growth, sample preparation, metabolites extraction, GC $\times$ GC analysis and data processing, which are described in the following subsections.

\section{Fungi growth}



Fungi culture
2. Sample preparation and metabolites extraction
3. GC $\times$ GC analysis

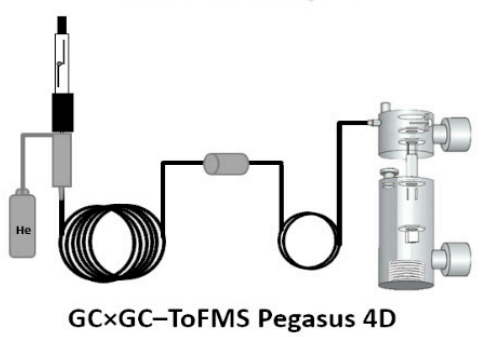

4. Data processing and interpretation



Figure 2. Workflow representation of the main stages for Candida species exometabolome analysis. The stages include yeast growth, sample preparation and metabolites extraction, GC $\times$ GC analysis, data processing and interpretation. Three independent assays were performed for each species.

\subsection{Yeasts Species and Growth Conditions}

Three yeasts were used in this study: Candida albicans SC5314 (ATCC MYA-2876), Candida tropicalis DSY472 (ATCC 750) and Candida glabrata NCCLS 84 (ATCC 90030). Fresh cultures were obtained by streaking each species on yeast glucose chloramphenicol $\left(10 \mathrm{gL}^{-1} \mathrm{D}\right.$-glucose and $5 \mathrm{gL}^{-1}$ yeast extract). Firstly, to evaluate the impact of growth conditions on metabolite production, C. albicans, C. tropicalis and C. glabrata were incubated in liquid YGC, at $37^{\circ} \mathrm{C}$, and incubation periods $(6,12,24$ and $48 \mathrm{~h})$. For each assay, 1 flask was prepared suspending the cultures in $50 \mathrm{~mL}$ of YGC $\left(10 \mathrm{gL}^{-1} \mathrm{D}\right.$-glucose and $5 \mathrm{gL}^{-1}$ yeast extract). Three independents assays were done for each condition, corresponding to a total of 3 flasks per condition (i.e., 3 yeast species $\times 4$ growth times, each one by 3 independent assays $=$ a total of 36 flasks). From each flask, it was collected $25 \mathrm{~mL}$ for metabolites profiling and $25 \mathrm{~mL}$ for cell concentration determination. Cell concentration was determined as colony-forming units per milliliter (CFU mL $\left.{ }^{-1}\right)$. The homogenized suspension was serially diluted in Ringer solution and aliquots of $100 \mu \mathrm{L}$ were spread on $\mathrm{YGC}_{\mathrm{A}}$ (5 replicates per dilution). The cell concentration of each aliquot was used to normalize the total areas of each chemical feature detected, therefore allowing the determination of specific metabolite production per cell.

\subsection{Exometabolome Profiling of Candida Species Cultures}

After incubation, $25 \mathrm{~mL}$ of each sample (YGC culture broth and respective medium control) were collected and centrifuged at $10,000 \mathrm{rpm}$, at $4{ }^{\circ} \mathrm{C}$ for $15 \mathrm{~min}$ (Centrifuge Beckman AVANTI). For HS-SPME procedure, $20 \mathrm{~mL}(1 / \beta$ ratio of 0.5$)$ of supernatant were transferred into a $60 \mathrm{~mL}$ glass vial, via a syringe with a $0.20 \mu \mathrm{m}$ filter pore. After the addition of $4 \mathrm{~g}$ of $\mathrm{NaCl}(\geq 99.5 \%$, Sigma-Aldrich, St. Louis, MO, USA) and stirring bar of $20 \mathrm{~mm} \times 5 \mathrm{~mm}$, the vial was capped with a silicone/polytetrafluoroethylene 
septum and an aluminum cap (Chromacol Ltd., Herts, UK). The samples were stored at $-80{ }^{\circ} \mathrm{C}$ until analysis.

The SPME holder for manual sampling and the coating fiber were purchased from Supelco (Aldrich, Bellefonte, PA, USA). The selected SPME device included a fused silica fiber coating, partially cross-linked with 50/30 $\mu \mathrm{m}$ divinylbenzene/carboxen ${ }^{\mathrm{TM}} /$ polydimethylsiloxane StableFlex $^{\mathrm{TM}}(1 \mathrm{~cm})$, which comprehends a wide range capacity of sorbing compounds with different physicochemical properties [36]. After defrosting, the vials were placed in a thermostated water bath and the headspace extraction was allowed to occur for $30 \mathrm{~min}$, at $50{ }^{\circ} \mathrm{C}$ and under continuous agitation at $350 \mathrm{rpm}$. Three independent aliquots were analyzed for each condition under study.

The SPME fiber was manually introduced into the GC $\times$ GC-ToFMS injection port and exposed during $30 \mathrm{~s}$ for thermal desorption into the heated injection port $\left(250^{\circ} \mathrm{C}\right)$. The instrumental parameters were defined according to a previous metabolomics studies [27,49]. The injection port was lined with a $0.75 \mathrm{~mm}$ I.D. splitless glass liner and splitless injections mode were used (30 s). The LECO Pegasus 4D (LECO, St. Joseph, MI, USA) GC $\times$ GC-ToFMS system comprised an Agilent GC 7890A gas chromatograph (Agilent Technologies, Inc., Wilmington, DE, USA), with a dual stage jet cryogenic modulator (licensed from Zoex) and a secondary oven, and mass spectrometer equipped with a ToF analyzer. An Equity-5 column (30 m $\times 0.32 \mathrm{~mm}$ I.D., $0.25 \mu \mathrm{m}$ film thickness, Supelco, Inc., Bellefonte, PA, USA) and a DB-FFAP column $(0.79 \mathrm{~m} \times 0.25 \mathrm{~mm}$ I.D., $0.25 \mu \mathrm{m}$ film thickness, J\&W Scientific Inc., Folsom, CA, USA) were used for first $\left({ }^{1} \mathrm{D}\right)$ and second $\left({ }^{2} \mathrm{D}\right)$ dimensions, respectively. The carrier gas was helium at a constant flow rate of $2.50 \mathrm{~mL} \mathrm{~min}^{-1}$. The following temperature programs were used: the primary oven temperature ranged from $40(1 \mathrm{~min})$ to $140{ }^{\circ} \mathrm{C}$ at $10^{\circ} \mathrm{C} \mathrm{min}^{-1}$, and then to $200^{\circ} \mathrm{C}$ ( $1 \mathrm{~min}$ ) at $7^{\circ} \mathrm{C} \mathrm{min}^{-1}$. The secondary oven temperature program was $15^{\circ} \mathrm{C}$ offset above the primary oven. Both the MS transfer line and MS source temperatures were $250^{\circ} \mathrm{C}$. The modulation period was $5 \mathrm{~s}$, keeping the modulator at $20^{\circ} \mathrm{C}$ offset above the primary oven, with hot and cold pulses by periods of 0.80 and $1.70 \mathrm{~s}$, respectively. The ToF analyzer was operated at a spectrum storage rate of 100 spectra s$^{-1}$, with a mass spectrometer running in the EI mode at $70 \mathrm{eV}$ and detector voltage of $-1499 \mathrm{~V}$, using an $\mathrm{m} / \mathrm{z}$ range of 35-350. Total ion chromatograms were processed using the automated data processing software ChromaTOF ${ }^{\circledR}(\mathrm{LECO})$ at a signal-to-noise threshold of 200. For identification purposes, the mass spectrum and retention times $\left({ }^{1} \mathrm{D}\right.$ and $\left.{ }^{2} \mathrm{D}\right)$ of the analytes were compared with standards, when available. Additionally, the identification process was done by comparing the mass spectrum of each peak with existing ones in mass spectral libraries, which included an in-house library of standards and two commercial databases (Wiley 275 and US National Institute of Science and Technology (NIST) V. 2.0-Mainlib and Replib). Moreover, a manual analysis of mass spectra was done, combining additional information like linear retention index (RI) value, which was experimentally determined according to van Den Dool and Kratz RI equation [50]. A $C_{8}-C_{20} n$-alkanes series was used for RI determination (the solvent $n$-hexane was used as the $C_{6}$ standard), comparing these values with reported ones in existing literature for chromatographic columns similar to the ${ }^{1} \mathrm{D}$ column mentioned above. The majority of the identified compounds $(>90 \%)$ presented similarity matches $>800 / 1000$. The deconvoluted total ion current GC $\times$ GC area data were used as an approach to estimate the relative content of each metabolite in the samples.

\subsection{Statistical Analysis}

Firstly, the peak areas data of all metabolites were extracted from the chromatograms and used to build the full data matrix from Candida species cultures consisting of 36 observations ( 3 yeast species $\times 4$ growth times, each one by 3 independent assays) and 129 variables. The complete list of these analytes is provided in Supplementary Information Table S1, including the areas of the three independent assays of each condition under study. The significance of the analytes detected in the yeast cultures (absolute GC areas) were compared to the ones that were detected in the YGC medium (control), through a two-sided Mann-Whitney test (using the SPSS software 20.0 (IBM, New York, NY, USA)). Differences corresponding to $p<0.05$ were considered significant. Thus, analytes that had 
the same statistical value between YGC medium and samples were excluded $(p>0.05$, analytes were marked with * in Supplementary Information Table S1), reducing the data from 129 to 126 variables (data set used for statistical analysis): of 36 observations ( 3 yeast species $\times 4$ growth times, each one by 3 independent assays) and 126 variables.

A hierarchical cluster analysis (HCA) combined with the heatmap visualization was applied for this dataset, the area of each variable was autoscaled and normalized by the sum for all samples (with GC peak previously normalized by CFU $\mathrm{mL}^{-1}$ ) using the MetaboAnalyst 3.0 (web software, The Metabolomics Innovation Centre (TMIC), Edmonton, AB, Canada). Moreover, two heatmaps were constructed with metabolites from the amino acid metabolism and the terpen-secondary metabolites, each one with 9 observations ( 3 yeast species $\times 1$ growth times $-6 \mathrm{~h}$, each one by 3 independent assays) and 5 variables (metabolites related with amino acid metabolism) and 29 variables (terpenic compounds), respectively. The significance of the analytes detected among the 3 species were compared, through a two-sided Mann-Whitney test (using the SPSS software 20.0 (IBM, New York, NY, USA)). Differences corresponding to $p<0.05$ were considered significant.

\section{Results and Discussion}

\subsection{Candida spp. Exometabolome}

In general, the growth conditions were established according to methods currently performed in clinical laboratories. The conventional procedures leading to yeast identification are often based on yeast growth on solid media, normally for 24-72 h [51]. However, in order to reduce the analysis time, different growth times were evaluated $(6,12,24$ and $48 \mathrm{~h})$, corresponding to the different cell cycle phases: $6 \mathrm{~h}$ corresponds to the end of lag phase; $12 \mathrm{~h}$ matches around the middle of the exponential phase; $24 \mathrm{~h}$ coincides with the end of the exponential phase and beginning of the stationary phase; and at $48 \mathrm{~h}$ yeasts are in the stationary phase $[52,53]$. Thus, to determine the volatile headspace components of Candida species cultures, samples were grown at $37^{\circ} \mathrm{C}$ during $6-48 \mathrm{~h}$, and metabolites were capture from headspace using SPME, as described in the material and methods section (2.2. Exometabolome profiling of Candida species cultures). After GC $\times$ GC instrumental analysis, data were collected for matrices construction with GC $\times$ GC peak area data and for metabolites identification.

For instance, Figure 3 shows the total ion chromatogram contour plot of the C.albicans cultures headspace volatile compounds at the four growth times: (a) $6 \mathrm{~h}$, (b) $12 \mathrm{~h}$, (c) $24 \mathrm{~h}$ and (d) $48 \mathrm{~h}$. These contour plots may be used as pictures of the $C$. albicans metabolome over time and unveil the data complexity. E,E-Farnesol were highlighted to reveal differences over time of growth, and it can be pointed out that the content of this metabolite increased until $24 \mathrm{~h}$ and then a decrease was observed for $48 \mathrm{~h}$ (Supplementary Information Figure S1). For C. glabrata and C. tropicalis, E,E-farnesol is not detected for the shortest growth time $(6 \mathrm{~h})$, which represent a particular characteristic of $C$. albicans.

Typically, the GC $\times$ GC contour plots from Candida species contain ca. 750 instrumental features (Figure 3), which identification represents a huge challenge. Thus, a comprehensive strategy was performed, based on the combination of the coinjection of standards, when available, and the analysis of acquired mass spectrum, RI and the comparison of these two chromatographic data with homemade and commercial databases. Additionally, the GC $\times$ GC structured chromatogram principle, a particular characteristic of the bidimensional GC, was used as a helpful tool. GC $\times$ GC structured chromatogram principle was a powerful tool in the identification procedure since compounds structurally related should be on similar 2D chromatographic space. Considering the set of columns used (non-polar/polar), the decrease in volatility (high ${ }^{1} t_{\mathrm{R}}$ ) is mainly related to the increasing in the number of carbons through the ${ }^{1} \mathrm{D}$. Otherwise, increasing in the ${ }^{2} t_{\mathrm{R}}$ corresponds to polarity increasing. 


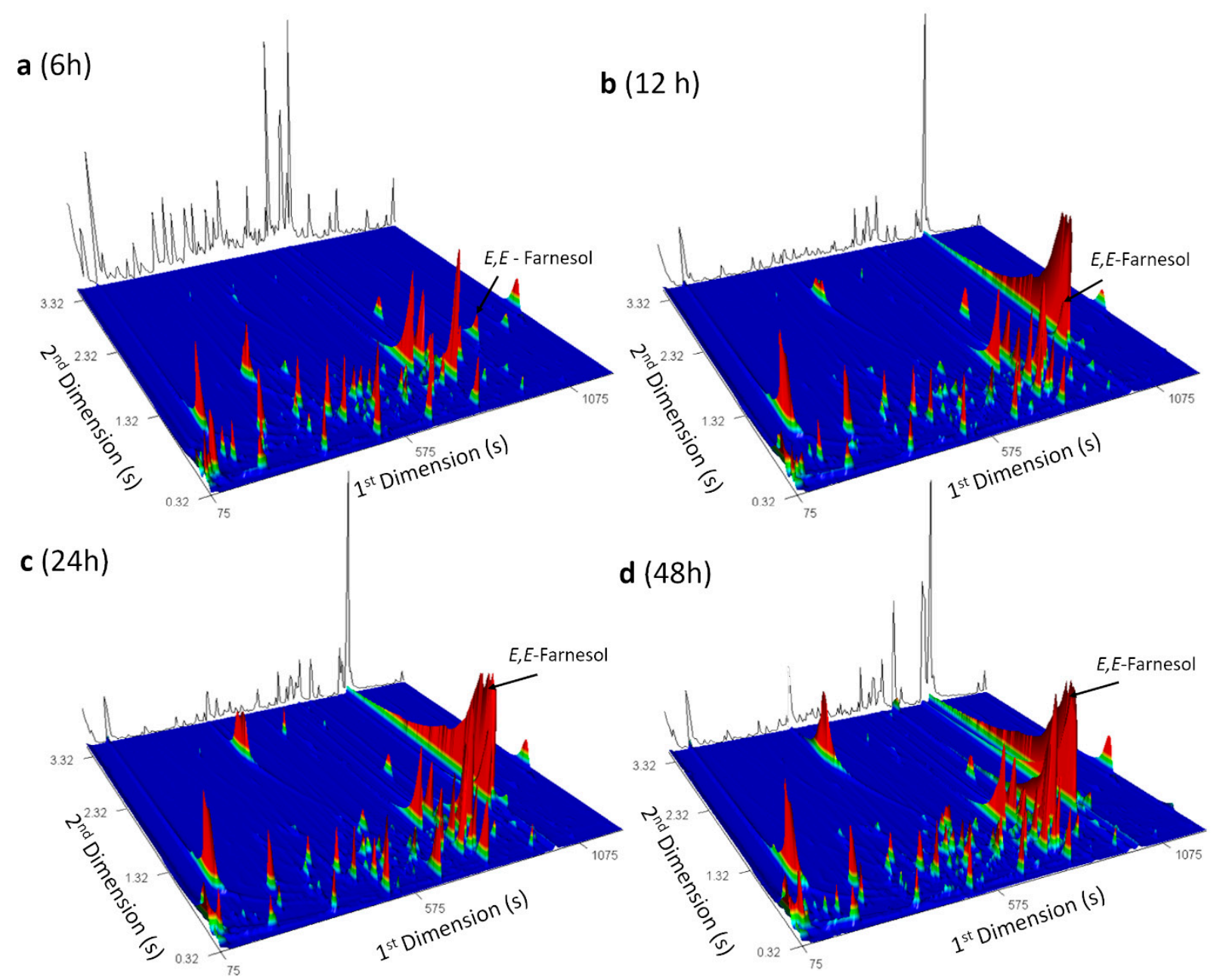

Figure 3. Selected GC $\times$ GC-ToFMS total ion chromatogram contour plot of the C. albicans cultures headspace volatile compounds at four growth times: (a) $6 \mathrm{~h}$, (b) $12 \mathrm{~h}$ (c) $24 \mathrm{~h}$ and (d) $48 \mathrm{~h}$ of culture headspace volatile compounds, used to illustrate a yeast metabolomic profile. E,E-Farnesol, an important quorum-sensing molecule, was highlighted. 
Figure 4 exhibits a blow-up of a part of three contour plots from the Candida species under study and illustrates the advantages of GC $\times$ GC-ToFMS, which allows the separation through the secondary ${ }^{2} \mathrm{D}$ column of analytes with similar volatility. For instance, geraniol $\left(\mathrm{C}_{10} \mathrm{H}_{18} \mathrm{O}\right)$ and 2-isoamyl-6-methyl pyrazine $\left(\mathrm{C}_{10} \mathrm{H}_{16} \mathrm{~N}_{2}\right)$ present similar volatility, and consequently they exhibited the same ${ }^{1} t_{\mathrm{R}}(595 \mathrm{~s})$. However, they were separated by the ${ }^{2} \mathrm{D}$ column $\left({ }^{2} t_{R}-0.610\right.$ and $0.710 \mathrm{~s}$, respectively) as they present different polarities. The compound 2-isoamyl-6-methyl pyrazine exhibited a LogP value slightly smaller than the geraniol (LogP-2.37 and 2.67, respectively, data obtained from https://www.chemeo.com/), which supports the relatively lower polarity of the geraniol and therefore the lower retention time in the ${ }^{2} \mathrm{D}$. Another important feature of the GC $\times \mathrm{GC}-\mathrm{ToFMS}$ is related to its sensitivity and spectral quality of the acquired data, which are crucial for identification purposes. A practical example can be observed in Figure 4 for geraniol, a trace component, presenting a 36-45 milliseconds wide GC $\times$ GC peak, which was identified at a mass spectral acquisition of 100 spectra/s. Spectral quality at this high acquisition rate is maintained due to the ToFMS with a continuous full-range mass spectral acquisition rate. As observed, the geraniol acquired mass spectrum was very similar (similarity value of 939/1000) compared to the Wiley database.

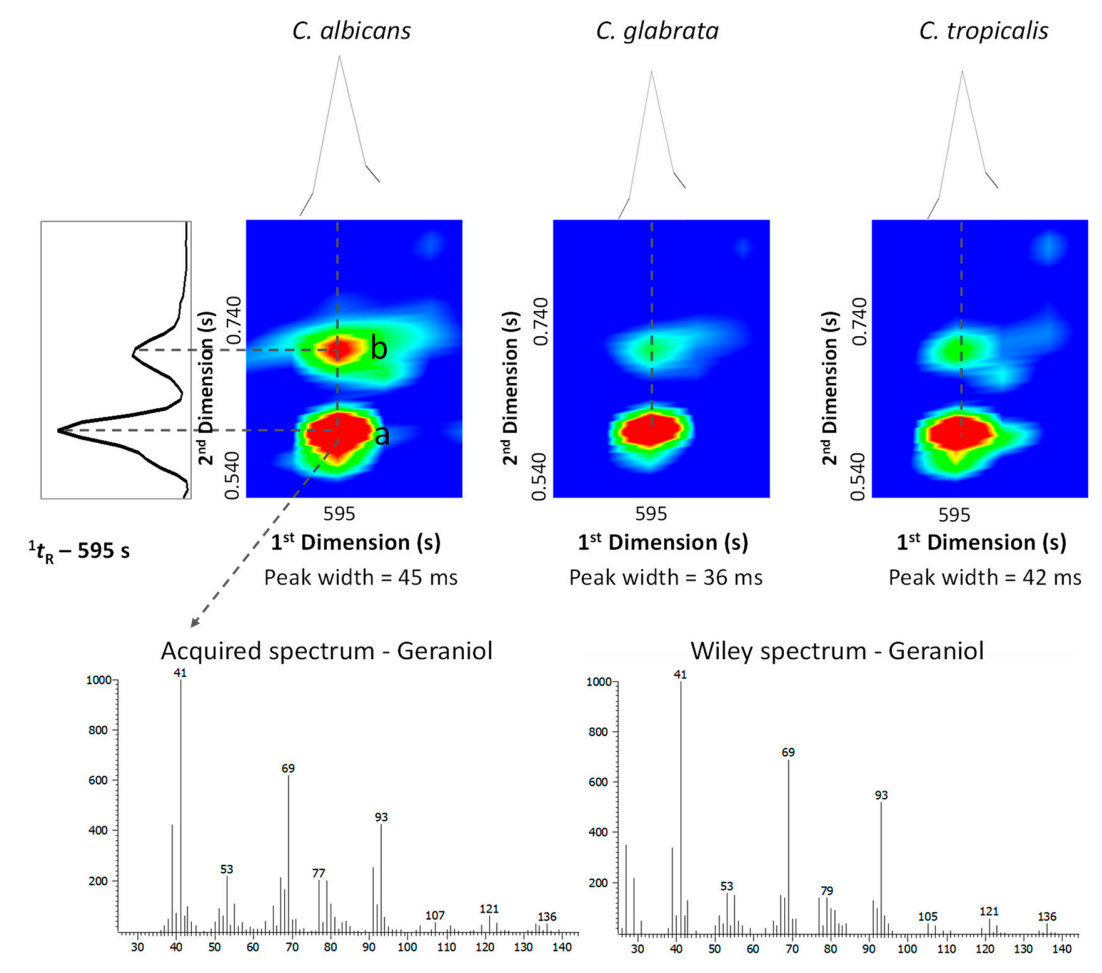

Figure 4. Blow-up of a part of GC $\times$ GC chromatogram contour plots from the C. albicans, C. glabrata and $C$. tropicalis $(12 \mathrm{~h})$ showing the separation, through the ${ }^{2} \mathrm{D}$, of $(\mathrm{a})$ geraniol $\left(\mathrm{C}_{10} \mathrm{H}_{18} \mathrm{O}\right)$ and $(\mathrm{b})$ 2-isoamyl-6-methyl pyrazine $\left(\mathrm{C}_{10} \mathrm{H}_{16} \mathrm{~N}_{2}\right)$, metabolites that exhibited the same retention time in the ${ }^{1} \mathrm{D}$. The 36-45 milliseconds wide geraniol GC $\times$ GC peak was identified at a mass spectral acquisition of 100 spectra/s. The geraniol acquired mass spectrum presented a similarity value of 939/1000 compared to the Wiley database.

The complete list of putatively identified metabolites is available in Table 1 and Supplementary Information Table S1. The GC $\times$ GC-ToFMS, a high sensitive and high throughput methodology, revealed the complexity of the matrices under study, as reflected in the dataset produced. From, all the detected instrumental features, a total number of 129 metabolites were putatively identified in Candida species metabolome, which are distributed over several chemical families such as acids, alcohols, aldehydes, hydrocarbons, esters, ketones, terpenic compounds including monoterpenic compounds and sesquiterpenes, norisoprenoids, phenols and sulphur compounds. This set of metabolites were 
reducing from 129 to 126, after removing the analytes that did not exhibit statistically significant differences $(p>0.05)$ between samples and YGC medium composition, used as background control: 3-methylheptyl acetate, levomenthol and $\alpha$-terpineol (Supplementary Information Table S1).

Considering this data set of 126 compounds, the number of metabolites per sample varied between 111 for C. tropicalis ( $6 \mathrm{~h}$ ) to 123 for C. glabrata (12 h; Supplementary Information Tables S2 and S3). Apart from acids that were not detected at $6 \mathrm{~h}$ for any of the species under study, there were components of the different chemical families in the four sampling moments. The number of shared and unique metabolites of each Candida species changed over the time-course experiment (6-48 h of growth; Figure 5). The number of shared compounds by all species was slightly higher (9.5\%) for longer growth times, which ranged from 105 at $6 \mathrm{~h}$ to 115 compounds at $24 \mathrm{~h}$ and $48 \mathrm{~h}$. At $6 \mathrm{~h}$ of growth time, $\alpha$-farnesene isomer, 2,3-dihydrofarnesol, $E$, E-farnesol and farnesal were the four unique metabolites of $C$. albicans, which may be further included in a potential pattern of biomarkers for the early contamination stage.
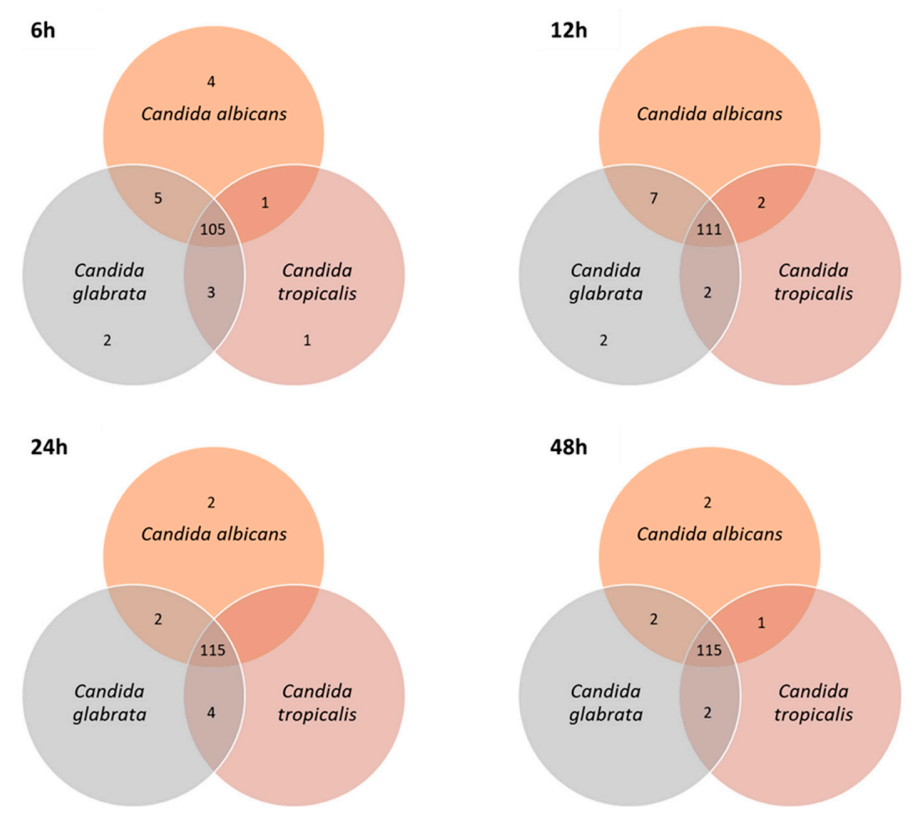

Figure 5. Total number of shared and unique metabolites of each Candida species over the time-course experiment.

Only $30 \%$ of the identified metabolites were previously reported in the literature for C. albicans samples, $9 \%$ for C. glabrata and 10\% for C. tropicalis, as shown in Table 1 . This represents a clear improvement from previous studies and validates this methodology for future studies of Candida spp. metabolism. The high number of metabolites that characterize the headspace of Candida species cultures allowed us to understand a network of pathways that may explain the origin of several detected metabolites (Table 1).

Altogether, this study allowed the identification of more compounds compared to previous studies, but more importantly, it allowed the detection of new metabolites that were never reported for these Candida species. These metabolites can be explored successfully to distinguish C. albicans from other Candida species with $6 \mathrm{~h}$ of growth time, which allows to infer that this data open opportunities in the future, it might be possible to distinguish Candida species at an early time and doing an early diagnostic of a microbiological agent can be possible and initiating the specific treatment, because often initiating empirical therapies based on clinical evaluation of patients, without having specific information on the etiological agent, impairs their treatment [54]. Additionally, the development and implementation of faster, accurate and cost-effective detection tests are extremely important in clinical studies. 
Table 1. Metabolites putatively identified in Candida species using HS-SPME/GC $\times$ GC-ToFMS. The information about ID Kegg, ID YMDB and respective pathways and the chromatographic data that helps their identification are also listed.

\begin{tabular}{|c|c|c|c|c|c|c|c|c|c|}
\hline \multirow{2}{*}{$\begin{array}{c}\text { Metabolite } \\
\text { ACIDS }\end{array}$} & \multirow[t]{2}{*}{ ID Kegg } & \multirow[t]{2}{*}{ ID YMDB } & \multirow[t]{2}{*}{ Pathways a } & \multirow[t]{2}{*}{$\begin{array}{c}\text { MSI } \\
\text { Level }^{b}\end{array}$} & \multirow[t]{2}{*}{$\mathrm{RI}_{\text {Calc }}{ }^{\mathrm{c}}$} & \multirow[t]{2}{*}{$\mathrm{RI}_{\text {Lit }}{ }^{\mathrm{d}}$} & \multicolumn{3}{|c|}{$\begin{array}{c}\text { Previously Reported for C. albicans, C. glabrata } \\
\text { and C. tropicalis }\end{array}$} \\
\hline & & & & & & & & & \\
\hline Octanoic acid & $\mathrm{C} 06423$ & YMDB00676 & Fatty acid biosynthesis & 1 & 1192 & 1188 [27] & - & - & - \\
\hline Nonanoic acid & C01601 & YMDB01761 & & 1 & 1303 & $1280[27]$ & - & - & - \\
\hline \multicolumn{9}{|l|}{ ALCOHOLS } & - \\
\hline Aliphatic & & & & & & & & & \\
\hline 1-Propanol & C05979 & YMDB00441 & Glycerolipid metabolism & 1 & 580 & 580 [27] & [28] & [28] & [28] \\
\hline 2-Methyl-1-propanol & C14710 & YMDB00573 & - & 1 & 612 & 612 [27] & {$[28,31]$} & {$[28,31]$} & {$[28,31]$} \\
\hline 1-Butanol & $\mathrm{C} 06142$ & YMDB01386 & Butanoate metabolism & 1 & 659 & 644 [27] & [27] & - & - \\
\hline 2/3-Methyl-1-butanol & - & YMDB00567 & Leucine degradation & 1 & $718 / 708$ & 718 [27] & {$[27,28,30,31]$} & {$[28,31]$} & {$[28,31]$} \\
\hline 1-Hexanol & - & YMDB01473 & - & 1 & 883 & 878 [27] & [27] & - & - \\
\hline 1-Heptanol & - & YMDB01475 & - & 1 & 980 & 975 [27] & [27] & - & - \\
\hline 1-Octen-3-ol & C14272 & YMDB01352 & - & 1 & 990 & 980 [27] & [27] & - & - \\
\hline 2-Ethyl-1-hexanol & $\mathrm{C} 02498$ & YMDB01330 & - & 2 & 1029 & 1029 [27] & {$[27,33]$} & - & [35] \\
\hline 1-Octanol & $\mathrm{C} 00756$ & YMDB00808 & - & 1 & 1084 & $1079[27]$ & [27] & - & - \\
\hline 1-Nonanol & C14696 & - & - & 2 & 1173 & $1173[27]$ & - & - & - \\
\hline 1-Decanol & $\mathrm{C} 01633$ & YMDB00826 & - & 1 & 1283 & $1278[27]$ & - & - & - \\
\hline 2-Undecanol & - & - & - & 1 & 1307 & $1301[27]$ & - & - & - \\
\hline 1-Dodecanol & $\mathrm{C} 02277$ & - & - & 1 & 1476 & $1476[27]$ & - & - & - \\
\hline \multicolumn{10}{|l|}{ Aromatic } \\
\hline 2-Phenyl-2-propanol & - & - & - & 2 & 1091 & $1090[27]$ & - & - & - \\
\hline 2-Phenylethanol & C05853 & YMDB01072 & Phenylalanine metabolism & 1 & 1126 & $1120[27]$ & {$[27,30]$} & [32] & {$[32,34]$} \\
\hline \multicolumn{10}{|l|}{ ALDEHYDES } \\
\hline Aliphatic & & & & & & & & & \\
\hline Acetaldehyde & $\mathrm{C} 00084$ & YMDB00022 & Phenylalanine metabolism & 1 & 548 & 548 [27] & [29] & [28] & - \\
\hline 2-Propenal & - & YMDB00812 & - & 2 & 582 & 563 [39] & - & - & - \\
\hline 2-Methyl-propanal & - & - & - & 2 & 591 & 576 [39] & - & - & - \\
\hline 3-Methylbutanal & C07329 & YMDB00499 & - & 2 & 624 & 633 [27] & - & - & - \\
\hline 2-Butenal & - & - & - & 2 & 633 & 633 [27] & [29] & - & - \\
\hline 2-Methyl-butanal & - & - & - & 2 & 649 & 643 [27] & - & - & - \\
\hline 3-Methyl-2-butenal & - & - & - & 2 & 792 & 789 [39] & - & - & - \\
\hline Hexanal & - & YMDB01759 & - & 1 & 801 & $801[27]$ & [27] & - & - \\
\hline
\end{tabular}


Table 1. Cont.

\begin{tabular}{|c|c|c|c|c|c|c|c|c|c|}
\hline \multirow{2}{*}{$\begin{array}{c}\text { Metabolite } \\
\text { Octanal }\end{array}$} & \multirow{2}{*}{$\begin{array}{c}\text { ID Kegg } \\
-\end{array}$} & \multirow{2}{*}{$\begin{array}{c}\text { ID YMDB } \\
\text { YMDB00824 }\end{array}$} & \multirow{2}{*}{$\begin{array}{c}\text { Pathways }^{\text {a }} \\
-\end{array}$} & \multirow{2}{*}{\begin{tabular}{|c|}
$\begin{array}{c}\text { MSI } \\
\text { Level }^{\text {b }}\end{array}$ \\
1 \\
\end{tabular}} & \multirow{2}{*}{$\begin{array}{r}\mathbf{R I}_{\text {Calc }}{ }^{\mathbf{c}} \\
1001\end{array}$} & \multirow{2}{*}{$\frac{\mathbf{R I}_{\text {Lit }}{ }^{\mathbf{d}}}{1001[27]}$} & \multicolumn{3}{|c|}{$\begin{array}{c}\text { Previously Reported for C. albicans, C. glabrat } \\
\text { and C. tropicalis }\end{array}$} \\
\hline & & & & & & & - & - & - \\
\hline Nonanal & - & - & - & 1 & 1106 & 1106 [27] & [27] & - & - \\
\hline Decanal & $\mathrm{C} 12307$ & YMDB01340 & - & 1 & 1212 & 1207 [27] & [27] & - & - \\
\hline 2-Undecenal & - & - & - & 2 & 1370 & 1364 [27] & [27] & - & - \\
\hline $\begin{array}{l}\text { Dodecanal } \\
\text { Aromatic }\end{array}$ & $\mathrm{C} 02278$ & - & - & 1 & 1432 & 1407 [27] & [27] & - & - \\
\hline Benzaldehyde & $\mathrm{C} 00261$ & YMDB01326 & $\begin{array}{l}\text { Toluene and xylene } \\
\text { degradation }\end{array}$ & 1 & 965 & $965[27]$ & {$[27,33]$} & - & - \\
\hline Benzeneacetaldehyde & - & YMDB00116 & Phenylalanine metabolism & 1 & 1046 & 1046 [27] & [27] & - & - \\
\hline 2,5-Dimethylbenzaldehyde & - & - & - & 2 & 1220 & $1208[55]$ & - & - & - \\
\hline 4-(1-Methylethyl)-benzaldehyde & - & - & - & 2 & 1226 & $1243[27]$ & - & - & - \\
\hline$\alpha$-Ethylidenbenzeneacetaldehyde & - & - & - & 2 & 1283 & 1280 [39] & - & - & - \\
\hline 2,4,6-Trimethylbenzaldehyde & - & - & - & 2 & 1314 & $1323[56]$ & - & - & - \\
\hline \multirow{2}{*}{\multicolumn{10}{|c|}{ HYDROCARBONS }} \\
\hline & & & & & & & & & \\
\hline Nonane & - & - & - & 1 & 900 & $900[27]$ & - & - & - \\
\hline 1-Dodecene & - & - & - & 2 & 1195 & 1191 [57] & - & - & - \\
\hline $\begin{array}{l}\text { Heptadecane } \\
\text { Aromatic }\end{array}$ & $\mathrm{C} 01816$ & - & - & 1 & 1701 & $1701[27]$ & {$[27]$} & - & - \\
\hline Toluene & C01455 & - & $\begin{array}{c}\text { Toluene and xylene } \\
\text { degradation }\end{array}$ & 1 & 753 & $759[27]$ & {$[27]$} & - & - \\
\hline Ethylbenzene & C07111 & - & Ethylbenzene degradation & 2 & 865 & $860[27]$ & - & - & - \\
\hline Styrene & C07083 & - & Styrene degradation & 2 & 889 & 895 [39] & - & - & - \\
\hline Isopropylbenzene & C14396 & - & - & 2 & 922 & $927[27]$ & - & - & - \\
\hline Propylbenzene & - & - & - & 2 & 953 & $953[27]$ & [27] & - & - \\
\hline$\alpha$-Methylstyrene & - & - & - & 2 & 980 & $985[27]$ & - & - & - \\
\hline 1,2,4,5-Tetramethylbenzene & C14534 & - & - & 2 & 1123 & 1123 [27] & - & - & - \\
\hline 1,4-Di-tert-butylbenzene & - & - & - & 2 & 1257 & $1264[58]$ & - & - & - \\
\hline Biphenyl & $\mathrm{C} 06588$ & - & Biphenyl degradation & 2 & 1389 & 1383 [27] & [27] & - & - \\
\hline 1-Butylheptylbenzene & - & - & - & 2 & 1636 & $1633[59]$ & - & - & - \\
\hline 1-Propyloctylbenzene & - & - & - & 2 & 1648 & $1645[59]$ & - & - & - \\
\hline 1-Butyloctylbenzene & - & - & - & 2 & 1738 & 1731 [59] & - & - & - \\
\hline 1-Propylnonylbenzene & - & - & - & 2 & 1751 & 1741 [59] & - & - & - \\
\hline 1-Ethyldecylbenzene & - & - & - & 2 & 1776 & $1764[59]$ & - & - & - \\
\hline \multicolumn{10}{|l|}{ ESTERS } \\
\hline Aliphatic & & & & & & & & & \\
\hline Ethyl acetate & C00849 & YMDB00569 & - & 1 & 601 & $601[27]$ & {$[28,31]$} & {$[28,31]$} & {$[28,31]$} \\
\hline Ethyl propanoate & - & YMDB01331 & - & 1 & 685 & $688[39]$ & [28] & [28] & [28] \\
\hline Isobutyl acetate & - & YMDB00572 & - & 2 & 763 & $769[27]$ & [31] & [31] & [31] \\
\hline Ethyl butanoate & - & YMDB01385 & - & 1 & 806 & $806[27]$ & {$[28,33]$} & [28] & [28] \\
\hline Butyl ethanoate & - & - & - & 2 & 818 & $818[27]$ & - & - & - \\
\hline Isoamyl ethanoate & - & YMDB00571 & - & 2 & 877 & $877[27]$ & - & - & - \\
\hline Hexyl ethanoate & - & YMDB01384 & - & 2 & 1017 & 1014 [39] & - & - & - \\
\hline
\end{tabular}


Table 1. Cont.

\begin{tabular}{|c|c|c|c|c|c|c|c|c|c|}
\hline \multirow{2}{*}{$\begin{array}{c}\text { Metabolite } \\
\text { Ethyl octanoate }\end{array}$} & \multirow{2}{*}{$\begin{array}{c}\text { ID Kegg } \\
\text { C12292 }\end{array}$} & \multirow{2}{*}{$\begin{array}{c}\text { ID YMDB } \\
\text { YMDB01354 }\end{array}$} & \multirow{2}{*}{$\begin{array}{c}\text { Pathways a }^{\text {a }} \\
-\end{array}$} & \multirow{2}{*}{$\begin{array}{c}\begin{array}{c}\text { MSI } \\
\text { Level }^{\mathbf{b}}\end{array} \\
1\end{array}$} & \multirow{2}{*}{$\begin{array}{r}\mathbf{R I}_{\text {Calc }}{ }^{\mathbf{c}} \\
1195\end{array}$} & \multirow{2}{*}{$\frac{\mathbf{R I}_{\text {Lit }}{ }^{\mathbf{d}}}{1195[27]}$} & \multicolumn{3}{|c|}{$\begin{array}{c}\text { Previously Reported for C. albicans, C. glabrata } \\
\text { and C. tropicalis }\end{array}$} \\
\hline & & & & & & & - & - & - \\
\hline Ethyl nonanoate & - & YMDB01354 & - & 1 & 1301 & 1295 [27] & - & - & - \\
\hline $\begin{array}{l}\text { 3-Hydroxy-2,4,4-trimethylpentyl } \\
\text { 2-methypropanoate }\end{array}$ & - & - & - & 2 & 1382 & $1376[27]$ & - & - & - \\
\hline $\begin{array}{l}\text { Propanoic acid, 2-methyl-, } \\
\text { 1-(1,1-dimethylethyl)- } \\
\text {-2-methyl-1,3-propanediyl ester }\end{array}$ & - & - & - & 2 & 1601 & 1607 [60] & - & - & - \\
\hline Lauryl acetate & - & - & - & 2 & 1613 & $1608[38]$ & - & - & - \\
\hline $\begin{array}{l}\text { Isopropyl myristate } \\
\text { Aromatic }\end{array}$ & D02296 & Aromatic & - & 2 & 1830 & $1834[60]$ & - & - & - \\
\hline Methyl benzoate & - & - & - & 2 & 1101 & $1101[27]$ & - & - & - \\
\hline 2-Benzylacrylic acid methyl ester & - & - & - & 2 & 1345 & 1339 [27] & - & - & - \\
\hline 2-Octyl benzoate & - & - & - & 2 & 1714 & 1708 [39] & - & - & - \\
\hline \multicolumn{9}{|l|}{ KETONES } & - \\
\hline 2-Butanone & $\mathrm{C} 02845$ & - & - & 1 & 577 & $590[27]$ & 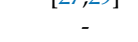 & - & - \\
\hline 2-Pentanone & C01949 & - & - & 2 & 677 & $664[27]$ & [31] & [31] & [31] \\
\hline 2,3-Pentanedione & - & YMDB01434 & - & 2 & 677 & $665[27]$ & - & - & - \\
\hline 4-Methyl-2-pentanone & - & - & - & 2 & 725 & $729[61]$ & - & - & - \\
\hline 3-Penten-2-one & - & - & - & 2 & 731 & 717 [27] & - & - & - \\
\hline 2,3-Heptanedione & - & - & - & 2 & 836 & $836[39]$ & - & - & - \\
\hline 5-Methyl-2-hexanone & - & - & - & 2 & 860 & $860[27]$ & - & - & - \\
\hline 4-Heptanone & - & - & - & 2 & 871 & $871[27]$ & - & - & - \\
\hline 6-Methyl-2-heptanone & - & - & - & 2 & 953 & $932[39]$ & - & - & - \\
\hline 2-Nonanone & - & YMDB01383 & - & 2 & 1095 & 1095 [27] & - & - & - \\
\hline Phenylacetone & C15512 & - & - & 2 & 1135 & 1135 [27] & - & - & - \\
\hline 1-Phenyl-1-butanone & - & - & - & 2 & 1258 & 1254 [27] & - & - & - \\
\hline 2-Undecanone & C01875 & YMDB01592 & - & 2 & 1301 & 1295 [27] & - & - & - \\
\hline 2-Tridecanone & - & - & - & 2 & 1501 & 1495 [27] & - & - & - \\
\hline \multicolumn{10}{|l|}{$\begin{array}{l}\text { TERPENIC COMPOUNDS } \\
\text { Monoterpenic compounds }\end{array}$} \\
\hline$\alpha$-Pinene & - & - & - & 1 & 932 & 937 [27] & - & - & - \\
\hline Verbenene & - & - & - & 2 & 953 & $958[27]$ & - & - & - \\
\hline 3-Carene & - & - & - & 1 & 1011 & 1009 [39] & - & - & - \\
\hline Limonene & $\mathrm{C} 06078$ & YMDB01727 & - & 1 & 1028 & 1028 [27] & - & - & - \\
\hline$\beta$-Ocimene & - & - & - & 2 & 1040 & 1039 [62] & - & - & - \\
\hline Dihydromyrcenol & - & - & - & 2 & 1073 & 1073 [27] & [27] & - & - \\
\hline Linalool tetrahydride & - & - & - & 2 & 1101 & $1101[27]$ & - & - & - \\
\hline Linalool & - & - & - & 1 & 1101 & 1107 [27] & - & - & - \\
\hline Fenchyl alcohol & $\mathrm{C} 02344$ & - & $\begin{array}{l}\text { Biosynthesis of secondary } \\
\text { metabolites }\end{array}$ & 2 & 1118 & $1123[27]$ & - & - & - \\
\hline Dihydroterpineol & - & - & - & 2 & 1145 & 1142 [63] & - & - & - \\
\hline Pinocarvone & C09884 & - & $\begin{array}{l}\text { Limonene and pinene } \\
\text { degradation }\end{array}$ & 2 & 1168 & 1168 [27] & - & - & - \\
\hline Borneol & C01411 & - & - & 1 & 1173 & 1174 [27] & - & - & - \\
\hline
\end{tabular}


Table 1. Cont.

\begin{tabular}{|c|c|c|c|c|c|c|c|c|c|}
\hline Metabolite & ID Kegg & ID YMDB & Pathways ${ }^{a}$ & $\begin{array}{c}\text { MSI } \\
\text { Level }^{b}\end{array}$ & $\mathrm{RI}_{\text {Calc }}{ }^{\mathrm{c}}$ & $\mathrm{RI}_{\text {Lit }} \mathrm{d}$ & \multicolumn{3}{|c|}{$\begin{array}{c}\text { Previously Reported for C. albicans, C. glabrata } \\
\text { and C. tropicalis }\end{array}$} \\
\hline Carvone & $\mathrm{C} 11383$ & YMDB01648 & $\begin{array}{l}\text { Limonene and pinene } \\
\text { degradation }\end{array}$ & 2 & 1251 & 1249 [39] & - & - & - \\
\hline Geraniol & C01500 & YMDB01700 & $\begin{array}{l}\text { Biosynthesis of secondary } \\
\text { metabolites }\end{array}$ & 1 & 1260 & 1265 [39] & - & - & - \\
\hline Endobornyl acetate & - & - & - & 2 & 1295 & 1289 [27] & [27] & - & - \\
\hline$\beta$-Terpenyl acetate & - & - & - & 2 & 1357 & $1351[27]$ & - & - & - \\
\hline \multicolumn{10}{|l|}{ Sesquiterpenic compounds } \\
\hline$\alpha$-Copaene & - & - & - & 2 & 1357 & 1370 [64] & - & - & - \\
\hline Longifolene & C09699 & - & $\begin{array}{l}\text { Biosynthesis of secondary } \\
\text { metabolites }\end{array}$ & 2 & 1418 & 1413 [27] & [33] & - & - \\
\hline$\beta$-Farnesene & - & - & - & 1 & 1460 & 1458 [39] & - & - & - \\
\hline Geranyl acetone & - & YMDB01701 & Propanoate metabolism & 2 & 1460 & 1458 [39] & - & - & - \\
\hline$\alpha$-Curcumene & - & - & - & 2 & 1494 & $1486[39]$ & - & - & - \\
\hline$\alpha$-Farnesene isomer & - & - & - & 2 & 1501 & 1495 [65] & - & - & - \\
\hline$\alpha$-Farnesene isomer & - & - & - & 2 & 1519 & $1515[39]$ & - & - & - \\
\hline Calamenene & - & - & - & 2 & 1530 & $1530[27]$ & - & - & - \\
\hline Nerolidol & C09704 & - & $\begin{array}{l}\text { Biosynthesis of secondary } \\
\text { metabolites }\end{array}$ & 1 & 1566 & 1566 [27] & [30] & - & - \\
\hline Caryophyllene oxide & C16908 & - & - & 2 & 1612 & $1610[66]$ & - & - & - \\
\hline 2,3-Dihydrofarnesol & - & - & - & 2 & 1695 & $1696[67]$ & - & - & - \\
\hline$E, E$-Farnesol & C01493 & YMDB00404 & $\begin{array}{l}\text { Biosynthesis of secondary } \\
\text { metabolites }\end{array}$ & 1 & 1731 & 1730 [39] & {$[26,30]$} & - & {$[34]$} \\
\hline $\begin{array}{c}\text { Farnesal } \\
\text { NORISOPRENOID }\end{array}$ & $\mathrm{C} 03461$ & - & Sesquiterpenoid biosynthesis & 2 & 1751 & 1744 [39] & - & - & - \\
\hline $\begin{array}{l}\alpha \text {-Methylionone } \\
\text { PHENOLS }\end{array}$ & - & - & - & 2 & 1489 & 1482 [27] & {$[27]$} & - & - \\
\hline 2-(1,1-Dimethylethyl)-4-methylphenol & - & - & - & 2 & 1366 & $1360[27]$ & - & - & - \\
\hline 5-Methyl-2,4-diisopropylphenol & - & - & - & 2 & 1466 & $1496[68]$ & - & - & - \\
\hline 2,4-Bis $\left(1,1^{\prime}\right.$-dimethylethyl)phenol & - & - & - & 2 & 1520 & 1514 [27] & [27] & - & - \\
\hline $\begin{array}{l}\text { Nonylphenol } \\
\text { SULPHUR COMPOUNDS }\end{array}$ & C14993 & - & - & 2 & 1760 & 1720 [69] & - & - & - \\
\hline Methanethiol & C00409 & YMDB00062 & $\begin{array}{l}\text { Cysteine and methionine } \\
\text { metabolism }\end{array}$ & 2 & 563 & 551 [39] & [29] & - & - \\
\hline Dimethyl disulfide & C08371 & YMDB01438 & - & 2 & 725 & $728[27]$ & [27] & [31] & [31] \\
\hline Thiazole & - & - & - & 2 & 736 & 727 [39] & - & - & - \\
\hline 2-Methyl-thiophene & - & - & - & 2 & 763 & 759 [27] & - & - & - \\
\hline 3-(Methylthio)propanal & - & YMDB01466 & - & 2 & 912 & $912[27]$ & - & - & - \\
\hline Dimethyl trisulfide & C08372 & YMDB01438 & - & 2 & 969 & $969[27]$ & - & - & - \\
\hline
\end{tabular}

a Metabolic pathways were also confirmed in Mbrole 2.0 related with Kegg [70] and Yeast Metabolome Data Base (YMDB) [71], being their KEGG and YMDB number mentioned; ${ }^{b}$ Level of metabolite identification according to [48]. (1) Identified compounds; (2) Putatively annotated compounds; (3) Putatively characterized compound classes; (4) Unknown compounds; ${ }^{\mathrm{c}} \mathrm{RI}_{\text {calc }}$ : linear retention index obtained through the modulated chromatogram; ${ }^{\mathrm{d}} \mathrm{RI}_{\mathrm{lit}}$ : linear retention index reported in the literature for one dimensional $\mathrm{GC}$ or $\mathrm{GC} \times \mathrm{GC}$ with a 5\%-Phenyl-methylpolysiloxane GC column or equivalent. 


\subsection{Exploring the Potential of Exometabolome on Candida Species Distinction}

A hierarchical cluster analysis (HCA) combined with the heatmap representation was constructed for an easy, rapid and global assessment of the Candida species metabolome over growth time and to evaluate the similarities and or differences between Candida species (Figure 6). The content of each metabolite was illustrated through a chromatic scale (from blue, minimum, to red, maximum), allowing a visual assessment of the relative abundance of each putatively identified compound.

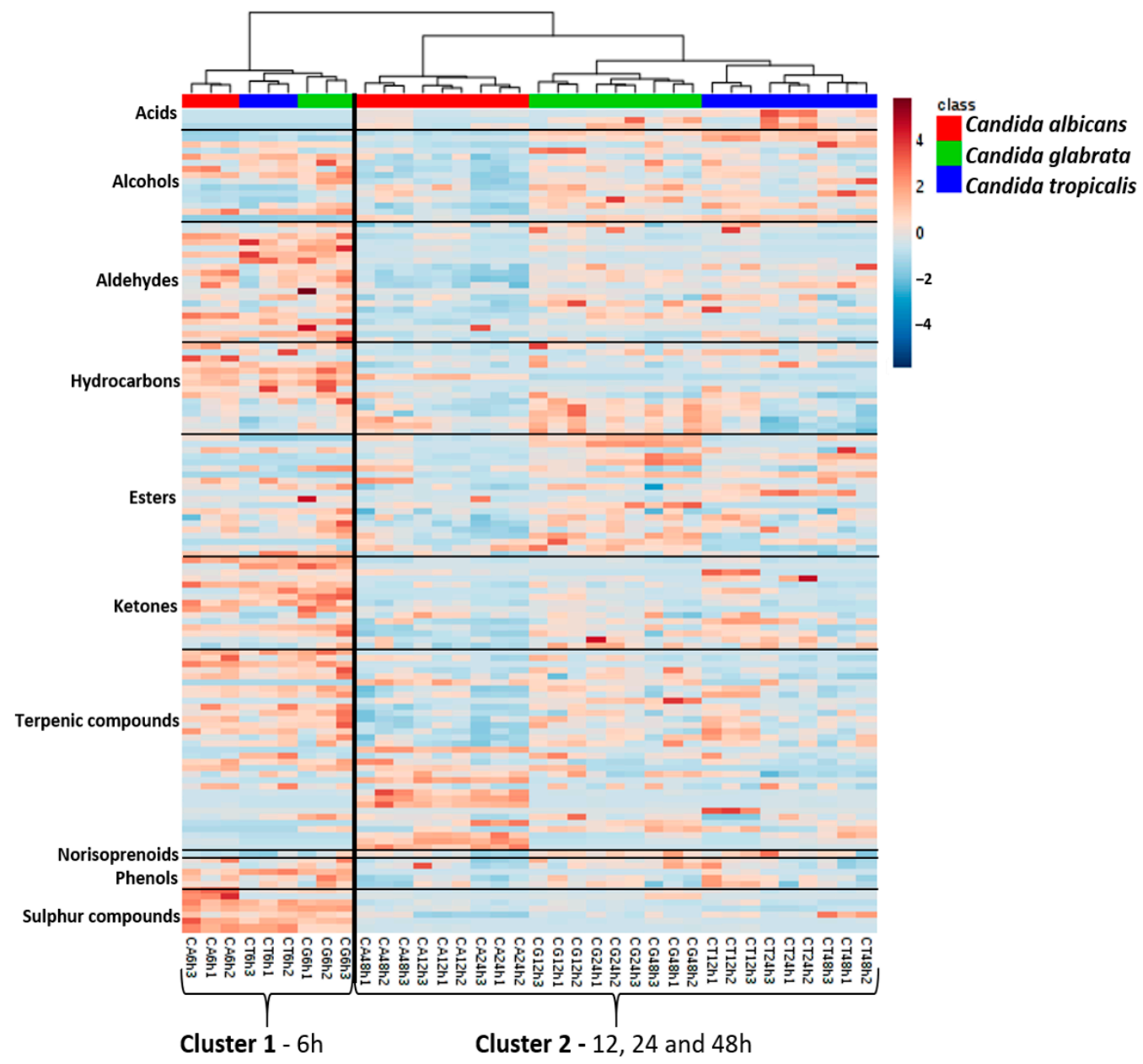

Figure 6. Heatmap and hierarchical cluster analysis representation of 126 metabolites putatively identified from Candida species cultures. The heatmap comprises the data obtained from the cultures of C. albicans, C. glabrata and C. tropicalis at $37^{\circ} \mathrm{C}$ and $6,12,24$ and $48 \mathrm{~h}$ of growth time. Cluster $1-$ samples from $6 \mathrm{~h}$ of growth, and Cluster 2-samples from 12, 24 and $48 \mathrm{~h}$ of growth. The area of each variable was autoscaled and normalized by the sum for all samples (with a GC peak previously normalized by CFU mL $\mathrm{mL}^{-1}$ ). $n=3$ for each condition under study. The content of each metabolite was illustrated through a chromatic scale (from blue, minimum, to red, maximum). Hierarchical cluster analysis using the Ward's cluster algorithm to the data set was also included.

It was possible to observe the formation of two main clusters: cluster 1-samples from $6 \mathrm{~h}$ of growth, and cluster 2-samples from 12, 24 and $48 \mathrm{~h}$ of growth, both including C. albicans, C. glabrata and C. tropicalis. In cluster 2 was possible to observe the formation of two secondary clusters: one of the C. albicans samples and other of C. glabrata and C. tropicalis, which allows one to infer a higher similarity between these two former species, taken into account the data set under study. The clustering analysis also reveals that although growth time is a fundamental factor for the metabolomic profile, for short or longer growth times, it is observed a clear distinction between the 3 species (Figure 6). 
In fact, C. albicans, C. glabrata and C. tropicalis showed different volatile patterns for 6-48 h growth time. Higher relative content of metabolites was observed at $6 \mathrm{~h}$ of growth for the families of aldehydes, hydrocarbons, ketones, terpenic compounds, phenols and sulphur compounds. The C. albicans achieved the highest content for sulphur compounds. For 12, 24 and $48 \mathrm{~h}$ of growth, it was observed a higher relative abundance of acids in C. tropicalis, a higher relative abundance of terpenic compounds in C. albicans, whereas higher relative abundances of hydrocarbons and esters were detected in C. glabrata. While volatile sulphur compounds and phenols show a higher relative content for early growth time in the three Candida species, acids show an opposite trend, presenting higher content at longer times of growth. In this case, Candida tropicalis exhibited a higher value of acid content.

The higher relative abundance observed for $6 \mathrm{~h}$ of growth corresponded to the end of the lag phase, and the metabolites content tended to decrease along with growth time, except for terpenic compounds. The analysis of the heatmap allowed us to conclude that the metabolomics footprinting seems to be dependent of the species under study. The heatmap shows the high complexity of Candida species cultures, mainly composed of their metabolome components, and their individual relative abundance may be explained by different constraints affecting the metabolic pathways of Candida species, upon different growth times.

E,E-Farnesol, $\alpha$-farnesene and farnesal showed a high relative content at 12,24 , and $48 \mathrm{~h}$ of growth. These results were in accordance with those reported by Martins et al. [30] showing that these metabolites are produced continuously by cells. For instance, farnesol is a quorum-sensing molecule, which is produced continuously in response to an increasing density of cells, such as the case of $24 \mathrm{~h}$ of continuous growth (Supplementary Information Figure S1), which are in accordance with a previous study [36]. The E,E-farnesol is a quorum-sensing molecule produced by C. albicans, namely for $6 \mathrm{~h}$ of growth, which has many effects, including filament inhibition of this polymorphic yeast. The response to the quorum-sensing compounds farnesol may also be mediated by the cAMP pathway, as repressive effects of these compounds on hyphal formation [36,72], a very relevant factor as the hyphal form seems to be more invasive.

Figure 7a shows the simplified schematic representation proposed to explain the metabolic pathways related to headspace released compounds from Candida species.

Some of the metabolites are known to play important roles in the biosynthesis of unsaturated fatty acids, such as ketones. 2/3-methyl-1-butanol and 2-phenylethanol were produced by the degradation of isoleucine/leucine and phenylalanine, respectively. 2-methyl-1-propanol was produced by the degradation of valine. Aldehydes and alcohols have also been related to fatty acids metabolism [70,73-75]. Esters can be produced through an enzyme-catalyzed condensation between an alcohol and an acetyl-CoA group, for example, isoamyl acetate can be produced through a reaction between 3-methyl-1-butanol and an acetyl-CoA group [76]. Sesquiterpenic compounds, such as farnesol can be biosynthesized through the mevalonate pathway, the isoprenoid precursors can be formed from acetyl-CoA, important to the formation farnesyl phosphate, that consequently promote the formation of sesquiterpenic compounds, consisting of three isoprene units $[26,70]$.

Two subsets of metabolites from $6 \mathrm{~h}$ of growth were selected and the corresponding heatmaps were constructed that also confirm the distinction among the tree Candida species: amino acid related metabolites (5 metabolites) and terpenic compounds secondary metabolites ( 29 metabolites), respectively in Figure 7b,c. Most of those metabolites (88\%) exhibited differences that were statistically significant between Candida species (differences corresponding to $p<0.05$ ). 


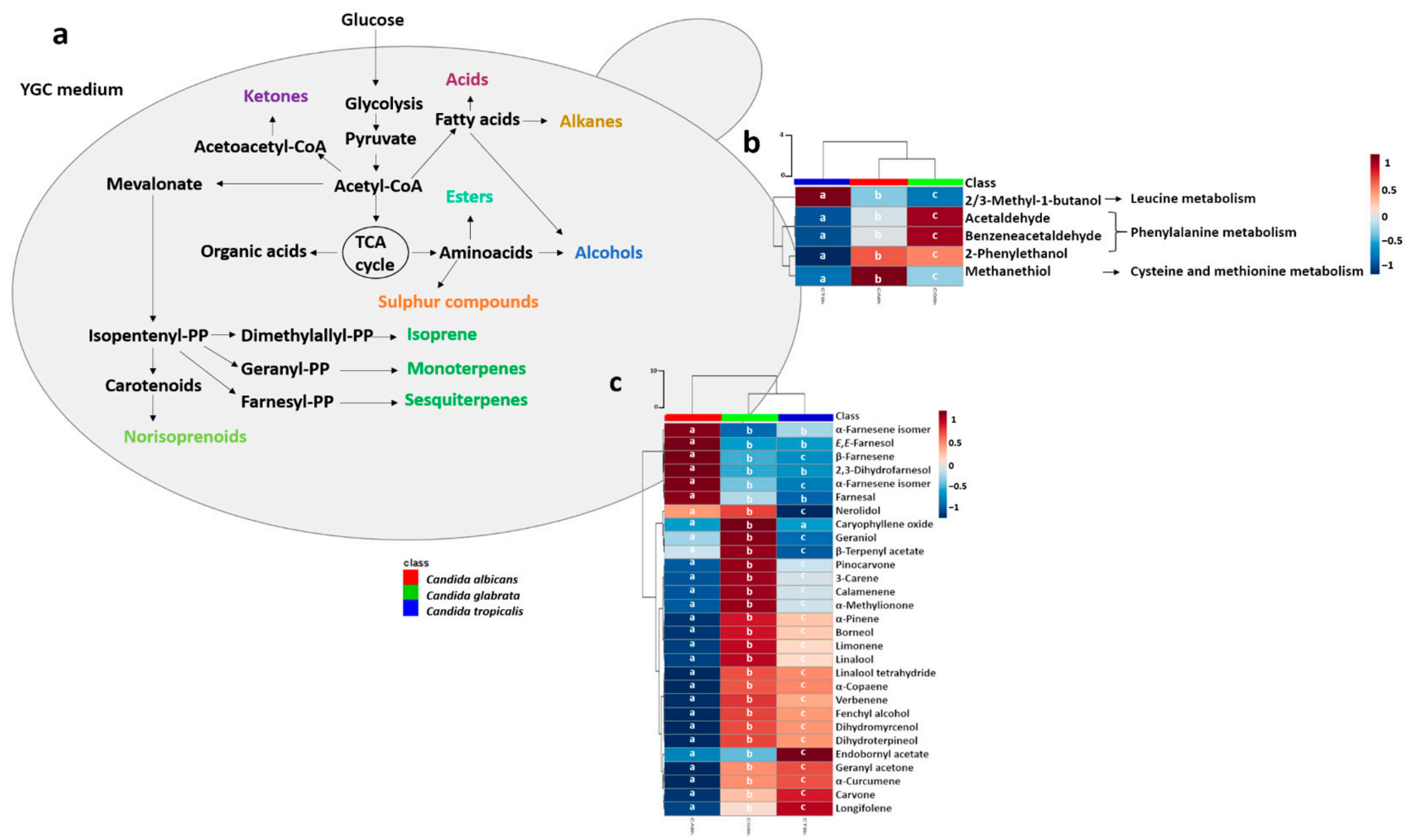

Figure 7. (a) Schematic representation proposed to explain Candida species metabolic pathways related to metabolites chemical families [70,71] and heatmap visualization of the metabolites from three strains of Candida species cultures: Candida albicans, Candida glabrata and Candida tropicalis at $6 \mathrm{~h}$ of growth time. (b) Amino acid metabolism related analytes; (c) Terpen-secondary metabolites [75]; Differences corresponding to $p<0.05$ were considered significant and were marked with a, $\mathrm{b}$ and c. 
Figure $7 \mathrm{~b}$ shows that $C$. albicans exhibited the highest content of methanethiol related to cysteine and methionine metabolism. Previous study [77], showed the relationship between the methionine and cysteine biosynthesis pathway and biofilm formation. The search of this pathway in the C. albicans genome database reveals that ECM17 encodes a putative enzyme that functions in sulphur amino acid biosynthesis. Additionally, the C. glabrata when comparing displays the lower biofilm metabolic activity in comparison with the other Candida species [78]. The higher content of methanethiol in C. albicans allows one to infer higher cysteine and methionine-related metabolic activity. Apart from $E, E$-farnesol, $\alpha$-farnesene, $\beta$-farnesene, 2,3-dihydrofarnesol and farnesal that are detected only from $C$. albicans cultures, in general, the C. glabrata exhibited the highest content of terpen-secondary metabolites (Figure 7c).

With results from this study, it is already possible to distinguish Candida albicans, based on a wide data set of metabolites or even on targeted chemical families, as for instance amino acid related metabolites and terpen-secondary metabolites. In fact, the Candida species have a specific pattern of metabolites related with several pathways, which enlarge the metabolomics knowledge available about these species.

\section{Conclusions}

The implemented methodology based on HS-SPME/GC $\times$ GC-ToFMS was shown to be suitable for the profiling of Candida species exometabolome, which represent the crucial step in the construction of a metabolomics workflow. Candida species metabolome presented a wide number of chemical features showing therefore the complexity of the Candida matrix, in which 126 metabolites were putatively identified within and distributed over several chemical families (acids, alcohols, aldehydes, hydrocarbons, esters, ketones, terpenic compounds including monoterpenic compounds and sesquiterpenes, norisoprenoids, phenols and sulphur compounds). This research represents the most detailed study on the volatile composition of Candida species.

A metabolomic signature of each Candida species under study was established, which were used for species distinction. Therefore, based on the developed metabolomic workflow described herein, the species metabotyping were performed and further research in a broader set of C. albicans collected from different conditions (clinical and environmental samples and cocultures, among others) might be valuable to study the $C$. albicans biodiversity and to contribute for microbial platform construction, useful for a more global fungal management. Finally, it is important to point out that, microbial metabolomics represents an important step for microorganism's insight and this research work represents a relevant contribution.

Supplementary Materials: The following are available online at http:/www.mdpi.com/2076-2607/8/12/1911/s1. Table S1. Full data set used for statistical analysis including the volatile components identified by HS-SPME/GC $\times$ GC-ToFMS from the headspace of C. albicans, C. glabrata and C. tropicalis strains cultures, along growth time: list of metabolites, respective information related with ID Kegg, ID YMDB, pathways and chromatographic area normalized by CFU mL-1. Table S2. Number of the metabolites within each chemical family, considering the growth times of Candida species and number of metabolites detected. Table S3. Metabolites detected for each Candida species over the time-course experiment. Figure S1. Cromatographic area and colony-forming units (CFU) mL-1 determined during a time-course 24 experiment for C. albicans (a), C. tropicalis (b) and C. glabrata (c).

Author Contributions: C.P.C. performed the microbial assays and the SPME/GC $\times$ GC-ToFMS data acquisition, processing and MS spectral analysis; performed the statistical analysis also contributed to the interpretation and global integration of the results, wrote the first draft of manuscript and the final revision; A.R.B. contributed to the study design, contributed to the metabolic data interpretation, integration and interpretation of the global result and contributed to the manuscript revision; A.A. contributed to the study design, the microbial assays supervision and the interpretation of the global result and manuscript final revision; S.M.R. contributed to the study design, the SPME/GC $\times$ GC-ToFMS data analysis and the respective data integration and interpretation of the global results and manuscript preparation and final revision. All authors read, reviewed and accepted the final manuscript. All authors have read and agreed to the published version of the manuscript. 
Funding: Funding is acknowledged from the FCT/MEC for the financial support to the QOPNA(UID/QUI/00062/2019), LAQV-REQUIMTE (UIDB/50006/2020) and CESAM (UIDP/50017/2020+UIDB/50017/2020), through national funds and where applicable co-financed by the FEDER, within the PT2020 Partnership Agreement.

Conflicts of Interest: The authors declare no conflict of interest.

\section{References}

1. Brown, G.D.; Denning, D.W.; Gow, N.A.R.; Levitz, S.M.; Netea, M.G.; White, T.C. Hidden killers: Human fungal infections. Sci. Transl. Med. 2012, 4. [CrossRef]

2. Pfaller, M.A.; Diekema, D.J. Epidemiology of invasive candidiasis: A persistent public health problem. Clin. Microbiol. Rev. 2007, 20, 133-163. [CrossRef]

3. Dadar, M.; Tiwari, R.; Karthik, K.; Chakraborty, S.; Shahali, Y.; Dhama, K. Candida albicans—Biology, molecular characterization, pathogenicity, and advances in diagnosis and control—An update. Microb. Pathog. 2018, 117, 128-138. [CrossRef]

4. Calderone, R.A.; Clancy, C.J. Candida and Candidiasis, 2nd ed.; Richard, A., Calderone, C.J.C., Eds.; American Society for Microbiology Press: Washington, DC, USA, 2011.

5. Pellon, A.; Sadeghi Nasab, S.D.; Moyes, D.L. New Insights in Candida albicans Innate Immunity at the Mucosa: Toxins, Epithelium, Metabolism, and Beyond. Front. Cell Infect. Microbiol. 2020, 10, 1-14. [CrossRef]

6. Wilson, L.S.; Reyes, C.M.; Stolpman, M.; Speckman, J.; Allen, K.; Beney, J. The direct cost and incidence of systemic fungal infections. Value Health 2002, 5, 26-34. [CrossRef]

7. Noble, S.M.; Gianetti, B.A.; Witchley, J.N. Candida albicans cell type switches and functional plasticity in the mammalian host. Nat. Rev. Microbiol. 2018, 15, 96-108. [CrossRef]

8. Kim, J.; Sudbery, P. Candida albicans, a major human fungal pathogen. J. Microbiol. 2011, 49, $171-177$. [CrossRef]

9. Da Silva Dantas, A.; Lee, K.K.; Raziunaite, I.; Schaefer, K.; Wagener, J.; Yadav, B.; Gow, N.A. Cell biology of Candida albicans-host interactions. Curr. Opin. Microbiol. 2016, 34, 111-118. [CrossRef]

10. Ting, S.Y.; Ishola, O.A.; Ahmed, M.A.; Tabana, Y.M.; Dahham, S.; Agha, M.T.; Musa, S.F.; Muhammed, R.; Than, L.T.L.; Sandai, D. Metabolic adaptation via regulated enzyme degradation in the pathogenic yeast Candida albicans. J. Mycol. Med. 2017, 27, 98-108. [CrossRef]

11. Hube, B. Fungal adaptation to the host environment. Curr. Opin. Microbiol. 2009, 12, 347-349. [CrossRef]

12. Dujon, B.; Sherman, D.; Fischer, G.; Durrens, P.; Casaregola, S.; Lafontaine, I.; De Montigny, J.; Marck, C.; Neuvéglise, C.; Talla, E.; et al. Genome evolution in yeasts. Nature 2004, 430, 35-44. [CrossRef]

13. Brunke, S.; Hube, B. Two unlike cousins: Candida albicans and C. glabrata infection strategies. Cell Microbiol. 2013, 15, 701-708. [CrossRef]

14. Lackey, E.; Vipulanandan, G.; Childers, D.S.; Kadosh, D. Comparative evolution of morphological regulatory functions in Candida species. Eukaryot. Cell 2013, 12, 1356-1368. [CrossRef]

15. Sibley, C.D.; Peirano, G.; Church, D.L. Molecular methods for pathogen and microbial community detection and characterization: Current and potential application in diagnostic microbiology. Infect. Genet. Evol. 2012, 12, 505-521. [CrossRef]

16. Cherkaoui, A.; Hibbs, J.; Emonet, S.; Tangomo, M.; Girard, M.; Francois, P.; Schrenzel, J. Comparison of Two Matrix-Assisted Laser Desorption Ionization-Time of Flight Mass Spectrometry Methods with Conventional Phenotypic Identification for Routine Identification of Bacteria to the Species Level. J. Clin. Microbiol. 2010, 48, 1169-1175. [CrossRef]

17. Posteraro, B.; Torelli, R.; De Carolis, E.; Posteraro, P.; Sanguinetti, M. Update on the laboratory diagnosis of invasive fungal infections. Mediterr. J. Hematol. Infect. Dis. 2011, 3. [CrossRef]

18. Franco-Duarte, R.; Černáková, L.; Kadam, S.; SKaushik, K.; Salehi, B.; Bevilacqua, A.; Corbo, M.R.; Antolak, H.; Dybka-Stępień, K.; Leszczewicz, M.; et al. Advances in chemical and biological methods to identify microorganisms-From past to present. Microorganisms 2019, 7, 130. [CrossRef]

19. Jahagirdar, V.L.; Davane, M.S.; Aradhye, S.C.; Nagoba, B.S. Candida species as potential nosocomial pathogens-A review. Electron. J. Gen. Med. 2018, 15, 1-5. [CrossRef] 
20. Kidd, S.E.; Chen, S.C.A.; Meyer, W.; Halliday, C.L. A New Age in Molecular Diagnostics for Invasive Fungal Disease: Are We Ready? Front. Microbiol. 2020, 10, 1-20. [CrossRef]

21. Bean, H.D.; Dimandja, J.M.D.; Hill, J.E. Bacterial volatile discovery using solid phase microextraction and comprehensive two-dimensional gas chromatography-time-of-flight mass spectrometry. J. Chromatogr. B 2012, 901, 41-46. [CrossRef]

22. Karageorgopoulos, D.E.; Vouloumanou, E.K.; Ntziora, F.; Michalopoulos, A.; Rafailidis, P.I.; Falagas, M.E. $\beta$-D-glucan assay for the diagnosis of invasive fungal infections: A meta-analysis. Clin. Infect. Dis. 2011, 52, 750-770. [CrossRef]

23. Rees, C.A.; Burklund, A.; Stefanuto, P.; Schwartzman, J.D.; Hill, J.E. Comprehensive volatile metabolic fingerprinting of bacterial and fungal pathogen groups Comprehensive volatile metabolic fi ngerprinting of bacterial and fungal pathogen groups. J. Breath Res. 2018, 12, 1-12. [CrossRef]

24. Sieniawska, E.; Sawicki, R.; Golus, J.; Georgiev, M.I. Untargetted metabolomic exploration of the mycobacterium tuberculosis stress response to cinnamon essential oil. Biomolecules 2020, 10, 357. [CrossRef] [PubMed]

25. Nazmul Huda, M.; Winnike, J.H.; Crowell, J.M.; O'Connor, A.; Bennett, B.J. Microbial modulation of host body composition and plasma metabolic profile. Sci. Rep. 2020, 10, 1-13. [CrossRef]

26. Hornby, J.M.; Jensen, E.C.; Lisec, A.D.; Tasto, J.J.; Jahnke, B.; Shoemaker, R.; Dussault, P.; Nickerson, K.W. Quorum Sensing in the Dimorphic Fungus Candida albicans Is Mediated by Farnesol Quorum Sensing in the Dimorphic Fungus Candida albicans Is Mediated by Farnesol. Appl. Environ. Microbiol. 2001, 67, 2982-2992. [CrossRef]

27. Costa, C.P.; Gonçalves Silva, D.; Rudnitskaya, A.; Almeida, A.; Rocha, S.M. Shedding light on Aspergillus Niger volatile exometabolome. Sci. Rep. 2016, 6, 1-13. [CrossRef]

28. Cailleux a Bouchara, J.; Daniel, V. Gas chromatography-mass spectrometry analysis of volatile organic compounds produced by some micromycetes. Chromatographia 1992, 34, 613-617. [CrossRef]

29. Scotter, J.M.; Langford, V.S.; Wilson, P.F.; McEwan, M.J.; Chambers, S.T. Real-time detection of common microbial volatile organic compounds from medically important fungi by Selected Ion Flow Tube-Mass Spectrometry (SIFT-MS). J. Microbiol. Methods 2005, 63, 127-134. [CrossRef]

30. Martins, M.; Henriques, M.; Azeredo, J.; Rocha, S.M.; Coimbra, M.A.; Oliveira, R. Morphogenesis control in Candida albicans and Candida dubliniensis through signaling molecules produced by planktonic and biofilm cells. Eukaryot. Cell 2007, 6, 2429-2436. [CrossRef]

31. Hertel, M.; Hartwig, S.; Schütte, E.; Gillissen, B.; Preissner, R.; Schmidt-Westhausen, A.M.; Paris, S.; Kastner, I.; Preissner, S. Identification of signature volatiles to discriminate Candida albicans, glabrata, krusei and tropicalis using gas chromatography and mass spectrometry. Mycoses 2016, 59, 117-126. [CrossRef]

32. Perl, T.; Jünger, M.; Vautz, W.; Nolte, J.; Kuhns, M.; Borg-von Zepelin, M.; Quintel, M. Detection of characteristic metabolites of Aspergillus fumigatus and Candida species using ion mobility spectrometry-Metabolic profiling by volatile organic compounds. Mycoses 2011, 54, 828-837. [CrossRef]

33. Karami, N.; Mirzajani, F.; Rezadoost, H.; Karimi, A.; Fallah, F.; Ghassempour, A.; Aliahmadi, A. Initial study of three different pathogenic microorganisms by gas chromatography-mass spectrometry. F1000Research 2017, 6. [CrossRef]

34. Martins, M.; Henriques, M.; Azeredo, J.; Rocha, S.M.; Coimbra, M.A.; Oliveira, R. Candida species extracellular alcohols: Production and effect in sessile cells. J. Basic Microbiol. 2010, 50 (Suppl. S1), 89-97. [CrossRef]

35. Nalli, S.; Horn, O.J.; Grochowalski, A.R.; Cooper, D.G.; Nicell, J.A. Origin of 2-ethylhexanol as a VOC. Environ. Pollut. 2006, 140, 181-185. [CrossRef]

36. Greguš, P.; Vlčková, H.; Buchta, V.; Kestřanek, J.; Křivčíková, L.; Nováková, L. Ultra high performance liquid chromatography tandem mass spectrometry analysis of quorum-sensing molecules of Candida albicans. J. Pharm. Biomed. Anal. 2010, 53, 674-681. [CrossRef]

37. Childers, D.S.; Kadosh, D. Filament condition-specific response elements control the expression of NRG1 and UME6, key transcriptional regulators of morphology and virulence in Candida albicans. PLoS ONE 2015, 10. [CrossRef] 
38. Alves, Z.; Melo, A.; Figueiredo, A.R.; Coimbra, M.A.; Gomes, A.C.; Rocha, S.M. Exploring the saccharomyces cerevisiae volatile metabolome: Indigenous versus commercial strains. PLoS ONE 2015, 10. [CrossRef]

39. Martins, C.; Brandão, T.; Almeida, A.; Rocha, S.M. Metabolomics strategy for the mapping of volatile exometabolome from Saccharomyces spp. widely used in the food industry based on comprehensive two-dimensional gas chromatography. J. Sep. Sci. 2017, 40, 2228-2237. [CrossRef]

40. Rocha, S.M.; Freitas, R.; Cardoso, P.; Santos, M.; Martins, R.; Figueira, E. Exploring the potentialities of comprehensive two-dimensional gas chromatography coupled to time of flight mass spectrometry to distinguish bivalve species: Comparison of two clam species (Venerupis decussata and Venerupis philippinarum). J. Chromatogr. A 2013, 1315, 152-161. [CrossRef]

41. Baptista, I.; Santos, M.; Rudnitskaya, A.; Saraiva, J.A.; Almeida, A. A comprehensive look into the volatile exometabolome of enteroxic and non-enterotoxic Staphylococcus aureus strains. Int. J. Biochem. Cell Biol. 2019, 108, 40-50. [CrossRef]

42. Matos, D.; Sá, C.; Cardoso, P.; Pires, A.; Rocha, S.M.; Figueira, E. Ecotoxicology and Environmental Safety The role of volatiles in Rhizobium tolerance to cadmium: Effects of aldehydes and alcohols on growth and biochemical endpoints. Ecotoxicol. Environ. Saf. 2019, 186. [CrossRef]

43. Cardoso, P.; Santos, M.; Freitas, R.; Rocha, S.M.; Figueira, E. Response of Rhizobium to Cd exposure: A volatile perspective. Environ. Pollut. 2017, 231, 802-811. [CrossRef]

44. Silva, I.; Rocha, S.M.; Coimbra, M.A.; Marriott, P.J. Headspace solid-phase microextraction combined with comprehensive two-dimensional gas chromatography time-of-flight mass spectrometry for the determination of volatile compounds from marine salt. J. Chromatogr. A 2010, 1217, 5511-5521. [CrossRef]

45. Prebihalo, S.E.; Berrier, K.L.; Freye, C.E.; Bahaghighat, H.D.; Moore, N.R.; Pinkerton, D.K.; Synovec, R.E. Multidimensional gas chromatography: Advances in instrumentation, chemometrics, and applications. Anal. Chem. 2018, 90, 505-532. [CrossRef]

46. Fiehn, O.; Robertson, D.; Griffin, J.; van der Werf, M.; Nikolau, B.; Morrison, N.; Sumner, L.W.; Goodacre, R.; Hardy, N.W.; Taylor, C.; et al. The metabolomics standards initiative (MSI). Metabolomics 2007, 3, 175-178. [CrossRef]

47. Goodacre, R.; Broadhurst, D.; Smilde, A.K.; Kristal, B.S.; Baker, J.D.; Beger, R.; Bessant, C.; Connor, S.; Capuani, G.; Craig, A.; et al. Proposed minimum reporting standards for data analysis in metabolomics. Metabolomics 2007, 3, 231-241. [CrossRef]

48. Sumner, L.W.; Amberg, A.; Barrett, D.; Beale, M.H.; Beger, R.; Daykin, C.A.; Fan, T.W.M.; Fiehn, O.; Goodacre, R.; Griffin, J.L.; et al. Proposed minimum reporting standards for chemical analysis Chemical Analysis Working Group (CAWG) Metabolomics Standards Inititative (MSI). Metabolomics 2007, 3, $211-221$. [CrossRef]

49. Salvador, Â.C.; Baptista, I.; Barros, A.S.; Gomes, N.C.; Cunha, Â.; Almeida, A.; Rocha, S.M. Can Volatile Organic Metabolites Be Used to Simultaneously Assess Microbial and Mite Contamination Level in Cereal Grains and Coffee Beans? PLoS ONE 2013, 8. [CrossRef]

50. Van Den Dool, H.; Kratz, P.D. A generalization of the retention index system including linear temperature programmed gas_Liquid partition chromatography. J. Chromatogr. A 1963, 11, 463-471. [CrossRef]

51. Deorukhkar, S.C.; Saini, S. Laboratory approach for diagnosis of candidiasis through ages. Int. J. Curr. Microbiol. Appl. Sci. 2014, 3, 206-218.

52. Thewes, S.; Moran, G.P.; Magee, B.B.; Schaller, M.; Sullivan, D.J.; Hube, B. Phenotypic screening, transcriptional profiling, and comparative genomic analysis of an invasive and non-invasive strain of Candida albicans. BMC Microbiol. 2008, 8, 1-16. [CrossRef]

53. Mahazar, N.H.; Zakuan, Z.; Norhayati, H.; MeorHussin, A.S.; Rukayadi, Y. Optimization of culture medium for the growth of Candida sp. and Blastobotrys sp. as starter culture in fermentation of cocoa beans (Theobroma cacao) using response surface methodology (RSM). Pak. J. Biol. Sci. 2017, 20, 154-159.

54. Drgona, L.; Khachatryan, A.; Stephens, J.; Charbonneau, C.; Kantecki, M.; Haider, S.; Barnes, R. Clinical and economic burden of invasive fungal diseases in Europe: Focus on pre-emptive and empirical treatment of Aspergillus and Candida species. Eur. J. Clin. Microbiol. Infect. Dis. 2014, 33, 7-21. [CrossRef]

55. Xu, L.L.; Han, T.; Wu, J.Z.; Zhang, Q.Y.; Zhang, H.; Huang, B.K.; Rahman, K.; Qin, L.P. Comparative research of chemical constituents, antifungal and antitumor properties of ether extracts of Panax ginseng and its endophytic fungus. Phytomedicine 2009, 16, 609-616. [CrossRef] 
56. Radulovic, N.; Blagojevic, P.; Palic, R. Comparative study of the leaf volatiles of Arctostaphylos uva-ursi (L.) Spreng. and Vaccinium vitis-idaea L. (Ericaceae). Molecules 2010, 15, 6168-6185. [CrossRef]

57. Caldeira, M.; Perestrelo, R.; Barros, A.S.; Bilelo, M.J.; Morete, A.; Camara, J.S.; Rocha, S.M. Allergic asthma exhaled breath metabolome: A challenge for comprehensive two-dimensional gas chromatography. J. Chromatogr. A 2012, 1254, 87-97. [CrossRef]

58. Poligné, I.; Collignan, A.; Trystram, G. Characterization of traditional processing of pork meat into boucané. Meat Sci. 2001, 59, 377-389. [CrossRef]

59. Silva, I.; Coimbra, M.A.; Barros, A.S.; Marriott, P.J.; Rocha, S.M. Can volatile organic compounds be markers of sea salt? Food Chem. 2015, 169, 102-113. [CrossRef]

60. Santos, M.C.; Nunes, C.; Rocha, M.A.M.; Rodrigues, A.; Rocha, S.M.; Saraiva, J.A.; Coimbra, M.A. High pressure treatments accelerate changes in volatile composition of sulphur dioxide-free wine during bottle storage. Food Chem. 2015, 188, 406-414. [CrossRef]

61. Ádámová, M.; Oriňák, A.; Halás, L. Retention indices as identification tool in pyrolysis-capillary gas chromatography. J. Chromatogr. A 2005, 1087, 131-141. [CrossRef]

62. Jalali-Heravi, M.; Zekavat, B.; Sereshti, H. Characterization of essential oil components of Iranian geranium oil using gas chromatography-mass spectrometry combined with chemometric resolution techniques. J. Chromatogr. A 2006, 1114, 154-163. [CrossRef]

63. Souza Ramos, M.F.; Carlos Siani, A.; Romero Tappin, M.R.; Cavalcante Guimarães, A.; Lahoz da Silva Ribeiro, J.E. Essential oils from oleoresins of Protium spp. of the Amazon region. Flavour Fragr. J. 2000, 15, 383-387. [CrossRef]

64. Petronilho, S.; Rocha, S.M.; Ramírez-Chávez, E.; Molina-Torres, J.; Rios-Chavez, P. Assessment of the terpenic profile of Callistemon citrinus (Curtis) Skeels from Mexico. Ind. Crops Prod. 2013, 46, 369-379. [CrossRef]

65. Zhao, J.; Guo, Y.; Suo, X.; Yuan, J. Comparative analysis of chemical components of essential oils from different samples of Rhododendron with the help of chemometrics method. Arch. Anim. Nutr. 2006, 60, 218-228. [CrossRef]

66. Jalali, H.T.; Petronilho, S.; Villaverde, J.J.; Coimbra, M.A.; Domingues, M.R.M.; Ebrahimian, Z.J.; Silvestre, A.J.; Rocha, S.M. Assessment of the sesquiterpenic profile of Ferula gummosa oleo-gum-resin (galbanum) from Iran. Contributes to its valuation as a potential source of sesquiterpenic compounds. Ind. Crops Prod. 2013, 44, 185-191. [CrossRef]

67. Lazarević, J.; Radulović, N.; Palić, R.; Zlatković, B. Chemical analysis of volatile constituents of berula erecta (Hudson) coville subsp. erecta (Apiaceae) from Serbia. J. Essent. Oil Res. 2010, 22, 153-156. [CrossRef]

68. Andriamaharavo, N.R. Retention Data; NIST Mass Spectrometry Data Center: Gaithersburg, MD, USA, 2014.

69. Bicalho, B.; Pereira, A.S.; Aquino Neto, F.R.; Pinto, A.C.; Rezende, C.M. Application of high-temperature gas chromatography-mass spectrometry to the investigation of glycosidically bound components related to cashew apple (Anacardium occidentale L. var. nanum) Volatiles. J. Agric. Food Chem. 2000, 48, 1167-1174. [CrossRef]

70. Kanehisa, M.; Goto, S. KEGG: Kyoto encyclopedia of genes and genomes. Nucleic Acids Res. 2000, 28, 27-30. [CrossRef]

71. Jewison, T.; Knox, C.; Neveu, V.; Djoumbou, Y.; Guo, A.C.; Lee, J.; Liu, P.; Mandal, R.; Krishnamurthy, R.; Sinelnikov, I.; et al. YMDB: The Yeast Metabolome Database. Nucleic Acids Res. 2012, 40, 815-820. [CrossRef]

72. Sudbery, P.E. Growth of Candida albicans hyphae. Nat. Rev. Microbiol. 2011, 9, 737-748. [CrossRef]

73. Lemfack, M.C.; Gohlke, B.-O.; Toguem, S.M.T.; Preissner, S.; Piechulla, B.; Preissner, R. mVOC 2.0: A database of microbial volatiles. Nucleic Acids Res. 2018, 46, 1261-1265. [CrossRef]

74. Lemfack, M.C.; Nickel, J.; Dunkel, M.; Preissner, R.; Piechulla, B. mVOC: A database of microbial volatiles. Nucleic Acids Res. 2014, 42, 744-748. [CrossRef]

75. López-Ibáñez, J.; Pazos, F.; Chagoyen, M. MBROLE 2.0-functional enrichment of chemical compounds. Nucleic Acids Res. 2016, 44, 201-204. [CrossRef]

76. Pires, E.J.; Teixeira, J.A.; Brányik, T.; Vicente, A.A. Yeast: The soul of beer's aroma-A review of flavour-active esters and higher alcohols produced by the brewing yeast. Appl. Microbiol. Biotechnol. 2014, 98, 1937-1949. [CrossRef] 
77. Li, D.D.; Wang, Y.; Dai, B.D.; Li, X.X.; Zhao, L.X.; Cao, Y.B.; Yan, L.; Jiang, Y.Y. ECM17-dependent methionine/cysteine biosynthesis contributes to biofilm formation in Candida albicans. Fungal Genet. Biol. 2013, 51, 50-59. [CrossRef]

78. Rodrigues, C.F.; Silva, S.; Henriques, M. Candida glabrata: A review of its features and resistance. Eur. J. Clin. Microbiol. Infect. Dis. 2014, 33, 673-688. [CrossRef]

Publisher's Note: MDPI stays neutral with regard to jurisdictional claims in published maps and institutional affiliations.

(C) 2020 by the authors. Licensee MDPI, Basel, Switzerland. This article is an open access article distributed under the terms and conditions of the Creative Commons Attribution (CC BY) license (http://creativecommons.org/licenses/by/4.0/). 